\title{
Siegesbeckiae Herba Extract and Chlorogenic Acid Ameliorate the Death of HaCaT Keratinocytes Exposed to Airborne Particulate Matter by Mitigating Oxidative Stress
}

\author{
Jae Won Ha (D) and Yong Chool Boo*(D) \\ Department of Molecular Medicine, School of Medicine, BK21 Plus KNU Biomedical Convergence Program, \\ Cell and Matrix Research Institute, Kyungpook National University, 680 Gukchaebosang-ro, Jung-gu, \\ Daegu 41944, Korea; jaewon1226@knu.ac.kr \\ * Correspondence: ycboo@knu.ac.kr; Tel.: +82-53-420-4946
}

\section{check for}

updates

Citation: Ha, J.W.; Boo, Y.C. Siegesbeckiae Herba Extract and Chlorogenic Acid Ameliorate the Death of HaCaT Keratinocytes Exposed to Airborne Particulate Matter by Mitigating Oxidative Stress. Antioxidants 2021, 10, 1762. https:// doi.org/10.3390/antiox10111762

\section{Academic Editors:}

Daniela-Saveta Popa, Laurian Vlase, Marius Emil Rusu and Ionel Fizesan

Received: 3 October 2021

Accepted: 2 November 2021

Published: 4 November 2021

Publisher's Note: MDPI stays neutral with regard to jurisdictional claims in published maps and institutional affiliations.

Copyright: (c) 2021 by the authors. Licensee MDPI, Basel, Switzerland. This article is an open access article distributed under the terms and conditions of the Creative Commons Attribution (CC BY) license (https:/ / creativecommons.org/licenses/by/ $4.0 /)$.

\begin{abstract}
Airborne particulate matter with a size of $10 \mu \mathrm{m}$ or less $\left(\mathrm{PM}_{10}\right)$ can cause oxidative damages and inflammatory reactions in the skin. This study was conducted to discover natural products that are potentially useful in protecting the skin from $\mathrm{PM}_{10}$. Among the hot water extracts of a total of 23 medicinal plants, Siegesbeckiae Herba extract (SHE), which showed the strongest protective effect against $\mathrm{PM}_{10}$ cytotoxicity, was selected, and its mechanism of action and active constituents were explored. SHE ameliorated $\mathrm{PM}_{10}$-induced cell death, lactate dehydrogenase (LDH) release, lipid peroxidation, and reactive oxygen species (ROS) production in HaCaT cells. SHE decreased the expression of KEAP1, a negative regulator of NRF2, and increased the expression of NRF2 target genes, such as HMOX1 and NQO1. SHE selectively induced the enzymes involved in the synthesis of GSH (GCL-c and GCL-m), the regeneration of GSH (GSR and G6PDH), and GSH conjugation of xenobiotics (GSTK1), rather than the enzymes that directly scavenge ROS (SOD1, CAT, and GPX1). SHE increased the cellular content of GSH and mitigated the oxidation of GSH to GSSG caused by $\mathrm{PM}_{10}$ exposure. Of the solvent fractions of SHE, the n-butyl alcohol (BA) fraction ameliorated cell death in both the absence and presence of $\mathrm{PM}_{10}$. The BA fraction contained a high amount of chlorogenic acid. Chlorogenic acid reduced $\mathrm{PM}_{10}$-induced cell death, $\mathrm{LDH}$ release, and ROS production. This study suggests that SHE protects cells from $\mathrm{PM}_{10}$ toxicity by increasing the cellular antioxidant capacity and that chlorogenic acid may be an active phytochemical of SHE.
\end{abstract}

Keywords: Siegesbeckiae Herba; Siegesbeckia pubescens Makino; airborne particulate matter; $\mathrm{PM}_{10}$; glutamate-cysteine ligase; nuclear factor erythroid 2-related factor 2; glutathione; chlorogenic acid; caffeic acid

\section{Introduction}

Air pollution, exacerbated by rapid climate change and industrial development, poses a major environmental factor that threatens human health [1]. Particulate matter (PM) suspended in the atmosphere is a complex material that contains various organic compounds and heavy metals [2]. Continued exposure to high concentrations of PM increases the incidence of various diseases, including respiratory and cardiovascular diseases, and mortality [3]. PM with an approximate diameter of less than 10 or $2.5 \mu \mathrm{m}$ is called $\mathrm{PM}_{10}$ and $\mathrm{PM}_{2.5}$, respectively [4].

As the interface between the body and the environment, the skin acts as a barrier to protect our body from environmental pollutants, but it is an organ directly exposed to environmental pollutants. The pores of the skin are large enough for PM to penetrate [5], and children with immature skin or patients with compromised skin barriers are relatively vulnerable to the percutaneous absorption and damage of PM compared to healthy adults [6-8]. PM exacerbates inflammatory skin diseases, such as atopic dermatitis, acne, and psoriasis by various mechanisms $[3,9]$. 
PM exposure stimulates $\mathrm{Ca}^{2+}$ signaling and increases the production of reactive oxygen species (ROS), such as superoxide radical $\left(\mathrm{O}_{2}{ }^{\bullet-}\right)$, hydrogen peroxide $\left(\mathrm{H}_{2} \mathrm{O}_{2}\right)$, and hydroxyl radical $\left({ }^{\bullet} \mathrm{OH}\right)$ [10]. Aryl hydrocarbons contained in PM increase the production of ROS in the process of metabolism [11]. Transition metal components also catalyze chemical reactions that generate ROS [12]. PM stimulates the NADPH oxidase family to increase ROS production [13]. Among the NADPH oxidase family, dual oxidase 2 has been reported to mediate the generation of ROS stimulated by $\mathrm{PM}_{10}$ or house dust mites $[14,15]$.

PM enhances the expression of cyclooxygenase 2 and increases the production of the eicosanoid mediator prostaglandin $\mathrm{E}_{2}[16,17]$. In addition, it stimulates the cell signaling system to increase the secretion of inflammatory cytokines, such as tumor necrosis factor- $\alpha$, interleukin (IL)-1 $\beta$, IL-6, and IL-8 [18]. PM also stimulates the expression of matrix metalloproteinases (MMPs), leading to increased degradation of the extracellular matrix, such as collagen [19]. Thus, there is a need for antioxidative countermeasures against skin inflammation and aging due to PM.

Plants are a good source of natural products with biological activities that are potentially useful for maintaining skin health and beauty [20-23]. It should be noted that certain phytochemicals can act as either antioxidants or prooxidants and have a positive or negative effect on cell survival depending on their type and concentration [24-27]. Phytochemicals that can reduce cellular oxidative stress directly or indirectly are expected to provide a useful strategy to reduce PM-induced skin inflammation and aging [28]. They can directly scavenge ROS or enhance cellular antioxidant capacity by inducing nuclear factor erythroid 2-related factor (NRF) 2-mediated gene expression [29]. In a previous study, our research team found that several phenolic compounds derived from terrestrial and marine plants, such as punicalagin, (-)-epigallocatechin-3-gallate, and dieckol relieve oxidative damage and reduce ROS production in HaCaT cells stimulated by $\mathrm{PM}_{10}$ and inhibit the subsequent cell signaling process and inflammatory responses [17,18,26].

This study aimed to discover a natural product that effectively relieves $\mathrm{PM}_{10}$-induced cytotoxicity and oxidative stress. To this end, the effects of several medicinal plant extracts on the viability of $\mathrm{HaCaT}$ keratinocytes exposed to $\mathrm{PM}_{10}$ were compared. As a result, Siegesbeckiae Herba extract (SHE) among the extracts of 23 medicinal plants, most effectively defended against $\mathrm{PM}_{10}$ cytotoxicity. Siegesbeckiae Herba generally refers to the dried aerial parts of Siegesbeckia orientalis L, Siegesbeckia pubescens Makino, and Siegesbeckia glabrescens Makino, and has been used as a traditional medicine in Korea, Japan, China, and Vietnam [30]. Studies on the phytochemicals and biological efficacy of SHE have been increasing recently [31,32]. However, studies on the protective action of SHE against PM cytotoxicity have not yet been reported. In the present study, the antioxidant properties of SHE prepared from the dried leaves of Siegesbeckia pubescens Makino were investigated in $\mathrm{HaCaT}$ cells exposed to $\mathrm{PM}_{10}$, with a special focus on the mechanism of action and active constituents. The results of this study suggest that SHE increases cell defense gene expression and thereby mitigates cell death and oxidative damage caused by $\mathrm{PM}_{10}$. It was also suggested that chlorogenic acid rather than caffeic acid may be the active constituent providing the cell protection effect.

\section{Materials and Methods}

\subsection{Reagents}

Standardized fine dust ( $\mathrm{PM}_{10}$-like) (European Reference Material ERM-CZ120), chlorogenic acid (Cat. C3878), and caffeic acid (Cat. C0625) were purchased from Sigma-Aldrich (St. Louis, MO, USA).

\subsection{Extracts of Medicinal Plants}

Medicinal plant extracts were obtained from the Plant Extract Bank of Korea (https: / / portal.kribb.re.kr/kpeb) (Cheongju, Korea). The plant sources and catalog numbers of the extracts used in this study are as follow; Castaneae Semen, CW01-011; Eucomiae Folium, CW01-052; Peucedani Japonici Radix, CW01-065; Melonis Calyx, CW02-003; Arisaematis 
Rhizoma, CW02-006; Eucomiae Ramulus, CW02-011; Dioscoreae Rhizoma, CW02-051; Mori Ramulus, CW02-060; Pruni Humilidis Semen, CW02-085; Angelicae tenuissimae Radix, CW03-008; Fagopyri Semen, CW03-011; Aconiti Jaluencis Tuber, CW03-082; Biotae Orientalis Folium, CW03-084; Gardeniae Fructus, CW03-087; Vitis Viniferae Caulis, CW03-100; Benincasae Semen, CW04-004; Akebiae Caulis, CW04-006; Pini Ramulus, CW04-021; Pini Pollen, CW04-022; Machili Thunbergi Cortex, CW04-056; Cyperi Rhizoma, CW04-069; Glycine Semen nigra, CW04-098; Siegesbeckiae Herba, CW04-100.

\subsection{Siegesbeckiae Herba Extract and Its Solvent Fractions}

Dried Siegesbeckiae Herba (Siegesbeckia pubescens Makino) was purchased from Sinsun Herb (http:/ / sinsunherb.co.kr) (Seoul, Korea) and its extract was prepared in this laboratory. Dried leaves ( $140 \mathrm{~g}$ ) were ground and extracted with $0.9 \mathrm{~L}$ water at $90{ }^{\circ} \mathrm{C}$ for $1 \mathrm{~h}$. The extracted solution was evaporated under reduced pressure to obtain the crude extract $(9 \mathrm{~g})$. The SHE was dispersed in $150 \mathrm{~mL}$ water and partitioned sequentially with an equal volume of methylene chloride (MC), ethyl acetate (EA), and n-butyl alcohol (BA). Evaporation of the organic solvents yielded MC fraction $(0.27 \mathrm{~g})$, EA fraction $(0.16 \mathrm{~g})$, and BA fraction $(0.46 \mathrm{~g})$. The aqueous layer was filtered to remove insoluble material (1.15 g) and then evaporated to obtain a water (WT) fraction $(6.64 \mathrm{~g})$.

\subsection{High-Performance Liquid Chromatography with Photodiode Array Detection (HPLC-DAD)}

HPLC-DAD analysis was carried out using a Waters Alliance HPLC system (Waters, Milford, MA, USA) consisting of an e2695 separation module and a 2996 photodiode array detector. The stationary phase was a Hector- $M C_{18}$ column $(4.6 \mathrm{~mm} \times 250 \mathrm{~mm}, 5 \mathrm{~m})$ (RS Tech Co., Daejeon, Korea). The mobile phase was a mixture of $0.1 \%$ phosphoric acid (A) and acetonitrile (B) with the following composition: 0-30 min, a linear gradient from 0 to $100 \% \mathrm{~B} ; 30-40 \mathrm{~min}, 100 \% \mathrm{~B}$. The solvent gradient program was as follows: $0-30 \mathrm{~min}$, a linear gradient from 0 to $100 \% \mathrm{~B} ; 30-40 \mathrm{~min}, 100 \% \mathrm{~B} ; 40-45 \mathrm{~min}$, a linear gradient from 100 to $0 \% \mathrm{~B}$. The flow rate of the mobile phase was $0.6 \mathrm{~mL} \mathrm{~min}^{-1}$. The sample injection volume was $10 \mu \mathrm{L}$.

\subsection{Cell Culture and $P M_{10}$ Treatment}

HaCaT cells, an immortalized human keratinocyte cell line originally established by Dr. Fusenig [33], were obtained from Dr. In-San Kim (Kyungpook National University, Daegu, Korea) and cultured in a closed incubator at $37^{\circ} \mathrm{C}$ in humidified air containing $5 \%$ $\mathrm{CO}_{2}$. Cells were administered DMEM/F-12 medium (GIBCO-BRL, Grand Island, NY, USA) containing $10 \%$ fetal bovine serum, $100 \mathrm{U} \mathrm{mL}^{-1}$ penicillin, $100 \mathrm{\mu g} \mathrm{mL}^{-1}$ streptomycin, $0.25 \mu \mathrm{g} \mathrm{mL}^{-1}$ amphotericin $\mathrm{B}$, and $10 \mu \mathrm{g} \mathrm{mL}^{-1}$ hydrocortisone every three days. Cells were cultured on 96-well, 12-well, or 6-well culture plates (SPL Life Sciences, Pocheon, Korea) for at least $24 \mathrm{~h}$ and then treated with either test materials, $\mathrm{PM}_{10}$, or both, at the specified concentrations for up to $48 \mathrm{~h}$.

\subsection{Cell Viability and Lactate Dehydrogenase (LDH) Release Assays}

Cell viability was assessed by a method using 3-(4,5-dimethylthiazol-2-yl)-2,5-diphenyl tetrazolium bromide (MTT) [34]. Cells were plated onto 96-well culture plates at $4 \times 10^{3}$ cells / well and maintained in a $200 \mu \mathrm{L}$ culture medium for $24 \mathrm{~h}$. The cells were treated with a vehicle or a test material and cultured in the absence or presence of $\mathrm{PM}_{10}\left(200 \mu \mathrm{g} \mathrm{mL}{ }^{-1}\right)$ for $48 \mathrm{~h}$. After discarding or saving the conditioned medium, adherent cells were incubated in a $100 \mu \mathrm{L}$ growth medium containing $1 \mathrm{mg} \mathrm{mL}^{-1} \mathrm{MTT}$ (Amresco, Solon, OH, USA) for $2 \mathrm{~h}$ in an incubator. After removing the medium and washing the cells with phosphate-buffered saline (PBS), the dye was extracted from the cells with $100 \mu \mathrm{L}$ dimethyl sulfoxide, and the absorbance of the extracts was measured at $570 \mathrm{~nm}$ with a SPECTROstar nano microplate reader (BMG LABTECH GmbH, Ortenberg, Germany).

The saved medium was used in the assay for LDH release using the TaKaRa LDH cytotoxicity detection kit (TaKaRa Bio Inc., Shiga, Japan). Briefly, $50 \mu \mathrm{L}$ aliquot of the medium 
diluted 2-times with PBS was mixed with $50 \mu \mathrm{L}$ of the reaction mixture prepared according to manufacturer protocol (this mixture contains sodium lactate, diaphorase, $\mathrm{NAD}^{+}$, and iodotetrazolium chloride). The final reaction mixture was incubated for $30 \mathrm{~min}$ at $25{ }^{\circ} \mathrm{C}$ and the absorbance was measured at $490 \mathrm{~nm}$ with a SPECTROstar nano microplate reader.

\subsection{Cellular Lipid Peroxidation Assay}

Cellular lipid peroxidation was assessed using a 2-thiobarbituric acid (TBA) method [35]. The cells were plated onto 6-well culture plates at $2 \times 10^{5}$ cells/well and maintained in a $2 \mathrm{~mL}$ culture medium for $24 \mathrm{~h}$. The cells were treated with vehicle or test material and cultured in the absence or presence of $\mathrm{PM}_{10}\left(200 \mu \mathrm{g} \mathrm{mL}^{-1}\right)$ for $48 \mathrm{~h}$. After discarding the medium and washing the cells with PBS, the adherent cells were lysed using the lysis buffer A (20 mM Tris-Cl, $2.5 \mathrm{mM}$ ethylenediamine- $N, N, N^{\prime}, N^{\prime}$-tetraacetic acid, $1.0 \%$ sodium dodecyl sulfate, $\mathrm{pH} 7.5$ ). The assay mixture consisted of $100 \mu \mathrm{L}$ cell lysate, $50 \mu \mathrm{L} 1.0 \%$ metaphosphoric acid, and $350 \mu \mathrm{L} 0.9 \%$ TBA (Sigma-Aldrich), which was then heated in a boiling water bath for $45 \mathrm{~min}$. After cooling, $500 \mu \mathrm{L} \mathrm{N}$-butyl alcohol (BA) was added to the mixture, which was then vortex-mixed and centrifuged at $13,000 \mathrm{rpm}$ for $15 \mathrm{~min}$ to produce two separate layers. The fluorescence intensity of the BA layer (excitation at $544 \mathrm{~nm}$ and emission at $590 \mathrm{~nm}$ ) was measured by using a Gemini EM fluorescence microplate reader (Molecular Devices, Sunnyvale, CA, USA). Data are presented as thiobarbituric acid-reactive substance (TBARS) levels corrected for protein contents. A standard curve was prepared using 1,1,3,3-tetramethoxypropane (Sigma-Aldrich) as a donor of malondialdehyde.

\subsection{Cellular ROS Production Assay}

Cellular ROS production was assessed by using $2^{\prime}, 7^{\prime}$-dichlorodihydrofluorescein diacetate (DCFH-DA), a cell-permeable fluorescent dye sensitive to changes in the redox state of a cell [36]. The cells were plated onto 12-well culture plates at $8 \times 10^{4}$ cells/well for $24 \mathrm{~h}$. Cells were pre-labeled with $10 \mu \mathrm{M}$ DCFH-DA (Sigma-Aldrich) for $60 \mathrm{~min}$ and treated with $200 \mu \mathrm{g} \mathrm{mL}^{-1} \mathrm{PM}_{10}$ alone or in combination with a test material at different concentrations for $60 \mathrm{~min}$. Cells were washed twice with PBS and the images of cells fluorescing due to the oxidation of DCFH-DA were obtained with a LEICA DMI3000 B microscope (Leica Microsystems GmbH, Wetzlar, Germany). The dye was extracted from cells using the lysis buffer A (150 $\mu \mathrm{L} /$ well). The extracted solution was centrifuged at $13,000 \mathrm{rpm}$ for $15 \mathrm{~min}$ and the supernatant was used for the measurement of fluorescence intensity (excitation at $485 \mathrm{~nm}$ and emission at $538 \mathrm{~nm}$ ) with a Gemini EM fluorescence microplate reader.

\subsection{Glutathione (GSH) and Glutathione Disulfide (GSSG) Assay}

GSH and GSSG contents were measured in a recycling assay using 5,5'-dithio-bis-2nitrobenzoic acid (DTNB) [37]. Cells were plated onto 6-well culture plates at $2 \times 10^{5}$ cells/well and maintained in a $2 \mathrm{~mL}$ culture medium for $24 \mathrm{~h}$. The cells were treated with vehicle or test material and cultured in the absence or presence of $\mathrm{PM}_{10}\left(200 \mu \mathrm{g} \mathrm{mL}^{-1}\right)$ for $24 \mathrm{~h}$. Cells were extracted using $5 \%$ meta-phosphoric acid ( $150 \mu \mathrm{L}$ per well). The extracted solution was centrifuged at 13,000 rpm for $15 \mathrm{~min}$ and the supernatant was used for the measurement of GSH/GSSG, using a GSH/GSSG assay kit (product number GT40) from Oxford Biomedical Research (Oxford, UK). Total GSH plus GSSG content was measured using the extract as it is, and the GSSG content was quantified after pre-scavenging GSH in the extract with a pyridine derivative. Absorbance change due to reduction of DTNB was measured at $412 \mathrm{~nm}$, and a calibration curve was prepared using a GSSG standard. The GSH content was calculated by subtracting the GSSG content from the total GSH plus GSSG content.

\subsection{Quantitative Reverse Transcriptase-Polymerase Chain Reaction ( $q R T-P C R$ )}

The mRNA levels of catalase (CAT), glucose 6-phosphate dehydrogenase (G6PDH), glutamate-cysteine ligase catalytic subunits (GCL-c), glutamate-cysteine ligase modifier subunit (GCL-m), glutathione disulfide reductase (GSR), glutathione peroxidase (GPX) 1, 
glutathione S-transferase (GST) k1, heme oxygenase (HMOX) 1, kelch-like ECH-associated protein (KEAP) 1, NRF2, NAD(P)H quinone oxidoreductase (NQO) 1, and superoxide dismutase (SOD) 1 and were determined by qRT-PCR using a StepOnePlus Real-Time PCR System (Applied Biosystems, Foster City, CA, USA). The cells were plated onto 6-well culture plates at $2 \times 10^{5}$ cells $/$ well and maintained in a $2 \mathrm{~mL}$ culture medium for $24 \mathrm{~h}$. The cells were treated with vehicle or test material and cultured in the absence or presence of $\mathrm{PM}_{10}\left(200 \mu \mathrm{g} \mathrm{mL}^{-1}\right)$ for $24 \mathrm{~h}$. Total cellular RNA was extracted from cells with an RNeasy kit (Qiagen, Valencia, CA, USA), and this RNA was used as a template for the synthesis of complementary DNA with a high-capacity cDNA archive kit (Applied Biosystems). Gene-specific primers for qRT-PCR were purchased from Macrogen (Seoul, Korea), and their nucleotide sequences are shown in Table 1 . The qRT-PCR reaction mixture $(20 \mu \mathrm{L})$ consisted of SYBR Green PCR Master Mix (Applied Biosystems), complementary DNA (60 ng), and gene-specific primer sets ( 2 picomole). Thermal cycling parameters were set as follows: $50^{\circ} \mathrm{C}$ for $2 \mathrm{~min}, 95^{\circ} \mathrm{C}$ for $10 \mathrm{~min}, 40$ amplification cycles of $95^{\circ} \mathrm{C}$ for $15 \mathrm{~s}$ and $60^{\circ} \mathrm{C}$ for $1 \mathrm{~min}$, and a dissociation step. In each run, the melting curve analysis confirmed the homogeneity of the PCR product. The mRNA levels of each gene were calculated relative to that of the internal reference, glyceraldehyde 3-phosphate dehydrogenase (GAPDH), using the comparative $\mathrm{Ct}$ method [37]. Ct is defined as the number of cycles required for the PCR signal to exceed the threshold level. Fold changes in the test group compared to the control group were calculated as $2^{-\Delta \Delta \mathrm{Ct}}$, where $\Delta \Delta \mathrm{Ct}=\Delta \mathrm{Ct}_{(\text {(est) }}-\Delta \mathrm{Ct}_{(\text {control) }}=$ $\left(\mathrm{Ct}_{\text {(gene, test) }}-\mathrm{Ct}_{\text {(reference, test })}\right)-\left(\mathrm{Ct}_{\text {(gene, control) }}-\mathrm{Ct}_{\text {(reference, control) })}\right)$.

Table 1. Sequences of primers used for the quantitative reverse transcriptase-polymerase chain reaction (qRT-PCR) of gene transcripts.

\begin{tabular}{|c|c|c|c|}
\hline Gene Name & GenBank Accession \# & $\begin{array}{l}\text { Forward }(F) \text { and Reverse }(R) \\
\text { Primer Sequences }\end{array}$ & Reference \\
\hline Catalase (CAT) & NM_001752.4 & $\begin{array}{l}\text { F: 5'-CATCGCCACATGAATGGATA-3' } \\
\text { R: 5'-CCAACTGGGATGAGAGGGTA-3' }\end{array}$ & {$[38]$} \\
\hline $\begin{array}{l}\text { Glucose 6-phosphate } \\
\text { dehydrogenase (G6PDH) }\end{array}$ & NM_001042351.3 & $\begin{array}{l}\text { F: 5'-GACATCCGCAAACAGAGTGA-3' } \\
\text { R: 5'-GGAGGCTGCATCATCGTACT-3' }\end{array}$ & {$[39]$} \\
\hline $\begin{array}{l}\text { Glutamate-cysteine ligase-catalytic } \\
\text { subunit (GCL-c) }\end{array}$ & NM_001197115.2 & $\begin{array}{l}\text { F: 5'-CTGGGAGTGATTTCTGCAT-3' } \\
\text { R: 5'-AGGAGGGGGCTTAAATCTCA-3' }\end{array}$ & {$[40]$} \\
\hline $\begin{array}{l}\text { Glutamate-cysteine ligase-modifier } \\
\text { subunit (GCL-m) }\end{array}$ & NM_002061.4 & $\begin{array}{l}\text { F: 5'-TTTGGTCAGGGAGTTTCCAG-3' } \\
\text { R: 5'-TGGTTTTACCTGTGCCCACT-3' }\end{array}$ & {$[40]$} \\
\hline Glutathione disulfide reductase (GSR) & NM_000637.5 & $\begin{array}{l}\text { F: 5'-CCAGCTTAGGAATAACCAGCGATGG-3' } \\
\text { R: 5'-GTCTTTTTAACCTCCTTGACCTGGGAGAAC-3' }\end{array}$ & [41] \\
\hline Glutathione peroxidase (GPX) 1 & NM_001329503.2 & $\begin{array}{c}\text { F: 5'-TTCCCGTGCAACCAGTTTG-3' } \\
\text { R: 5'-GGACGTACTTGAGGGAATTCAGA-3' }\end{array}$ & [42] \\
\hline Glutathione S-transferase (GST) к1 & NM_001143679.2 & $\begin{array}{l}\text { F: 5'-TCTCCAGATTCCCATCCACTTCCC-3' } \\
\text { R: 5'-CTGCGGCTCGGTGATGTCTTC-3' }\end{array}$ & [43] \\
\hline $\begin{array}{l}\text { Glyceraldehyde 3-phosphate } \\
\text { dehydrogenase (GAPDH) }\end{array}$ & NM_001357943.2 & $\begin{array}{l}\text { F: 5'-ATGGGGAAGGTGAAGGTCG-3' } \\
\text { R: 5'-GGGGTCATTGATGGCAACAA-3' }\end{array}$ & [17] \\
\hline Heme oxygenase (HMOX) 1 & NM_002133.3 & $\begin{array}{l}\text { F: 5'-CGGGCCAGCAACAAAGTG-3' } \\
\text { R: 5'-ACTGTCGCCACCAGAAAGCT-3' }\end{array}$ & [44] \\
\hline Kelch-like ECH-associated protein (KEAP) 1 & NM_012289.4 & $\begin{array}{l}\text { F: 5'-CAGAGGTGGTGGTGTTGCTTAT-3' } \\
\text { R: 5'-AGCTCGTTCATGATGCCAAAG-3' }\end{array}$ & [45] \\
\hline $\mathrm{NAD}(\mathrm{P}) \mathrm{H}$ quinone oxidoreductase (NQO) 1 & NM_001025434.2 & $\begin{array}{c}\text { F: 5'-GCACTGATCGTACTGGCTCACT-3' } \\
\text { R: 5'-CCACCACCTCCCATCCTTT-3' }\end{array}$ & This study \\
\hline $\begin{array}{l}\text { Nuclear factor erythroid 2-related factor } \\
\text { (NRF) } 2\end{array}$ & NM_006164.5 & $\begin{array}{l}\text { F: 5'-GAGAGCCCAGTCTTCATTGC-3' } \\
\text { R: 5'-ACTGGTTGGGGTCTTGTGTG-3' }\end{array}$ & This study \\
\hline Superoxide dismutase (SOD) 1 & NM_000454.5 & $\begin{array}{l}\text { F: 5'-AGGGCATCATCAATTTCGAG-3' } \\
\text { R: 5'-ACATTGCCCAAGTCTCCAAC-3' }\end{array}$ & [46] \\
\hline
\end{tabular}




\subsection{Western Blotting}

Western blotting was performed as previously described [47]. Primary antibodies for GCL-c (\#390811), GCL-m (\#55586), G6PDH (\#373886), and $\beta$-actin (\#47778) were purchased from Santa Cruz Biotechnology (Santa Cruz, CA, USA). Anti-rabbit IgG (\#2357) and antigoat IgG (\#2020) secondary antibodies were purchased from Santa Cruz Biotechnology, and anti-mouse IgG (\#7076) secondary antibody was purchased from Cell Signaling Technology (Danvers, MA, USA). Antibodies were diluted in TBST (137 mM sodium chloride, $20 \mathrm{mM}$ Tris, $0.1 \%$ Tween 20, pH 7.6.) containing 5\% skim milk. Proteins in cell lysate samples were denatured by adding Laemmli $5 \times$ sample buffer and heating at $95{ }^{\circ} \mathrm{C}$ for $5 \mathrm{~min}$. Proteins $(40 \mu \mathrm{g})$ were resolved with $10 \%$ SDS-polyacrylamide gel electrophoresis at $80 \mathrm{~V}$ and electrically transferred to a polyvinylidene difluoride membrane (Amersham Pharmacia, Little Chalfont, UK) at $4{ }^{\circ} \mathrm{C}$ overnight. After blocking incubation with TBST containing $5 \%$ skim milk, the membrane was incubated with the primary antibody at $4{ }^{\circ} \mathrm{C}$ overnight, followed by incubation with the secondary antibody at room temperature for $1 \mathrm{~h}$. The target protein bands were visualized with a chemiluminescence method using the picoEPD Western Reagent kit (ELPIS-Biotech, Daejeon, Korea). The captured blot images were analyzed using the Image J program from U.S. National Institutes of Health (Bethesda, MD, USA).

\subsection{Statistical Analysis}

Data are expressed as mean \pm standard deviation (SD) of three or more independent experiments. Experimental results were statistically analyzed using SigmaStat v.3.11 software (Systat Software Inc., San Jose, CA, USA). The presence of significantly different group means was determined using a one-way analysis of variance (ANOVA) at $p<0.05$ level. Dunnett's test was then used to compare each experimental group with the control group. Alternatively, Duncan's multiple range test was used to compare all groups to each other.

\section{Results}

\subsection{Effects of Medicinal Plant Extracts on the PM10-Induced Toxicity in HaCaT Keratinocytes}

A preliminary experiment was performed to select plant extracts that alleviate the cytotoxicity of $\mathrm{PM}_{10}$. HaCaT cells were treated with each plant extract at $50 \mu \mathrm{g} \mathrm{mL}^{-1}$ and exposed to $200 \mu \mathrm{g} \mathrm{mL}^{-1} \mathrm{PM}_{10}$ for $48 \mathrm{~h}$. As shown in Figure 1, in the case of the vehicle control group, the cell viability decreased by about $40 \%$ by $\mathrm{PM}_{10}$ exposure. Of the 23 plant extracts tested, seven plant extracts showed their own toxicity, significantly reducing cell viability in the absence of $\mathrm{PM}_{10}$; they are the extracts derived from Eucomiae Folium, Eucomiae Ramulus, Mori Ramulus, Angelicae tenuissimae Radix, Gardeniae Fructus, Akebiae Caulis, and Pini Pollen. On the other hand, the nine plant extracts had no effect on cell viability by themselves, and also mitigated the decrease in cell viability caused by $\mathrm{PM}_{10}$; they are the extracts derived from Castaneae Semen, Peucedani Japonici Radix, Arisaematis Rhizoma, Dioscoreae Rhizoma, Biotae Orientalis Folium, Vitis Viniferae Caulis, Machili Thunbergi Cortex, Cyperi Rhizoma, and Siegesbeckiae Herba. Among them, Siegesbeckiae Herba extract (SHE) most effectively restored the viability of $\mathrm{PM}_{10}$-exposed cells, so this extract was selected for subsequent experiments. 


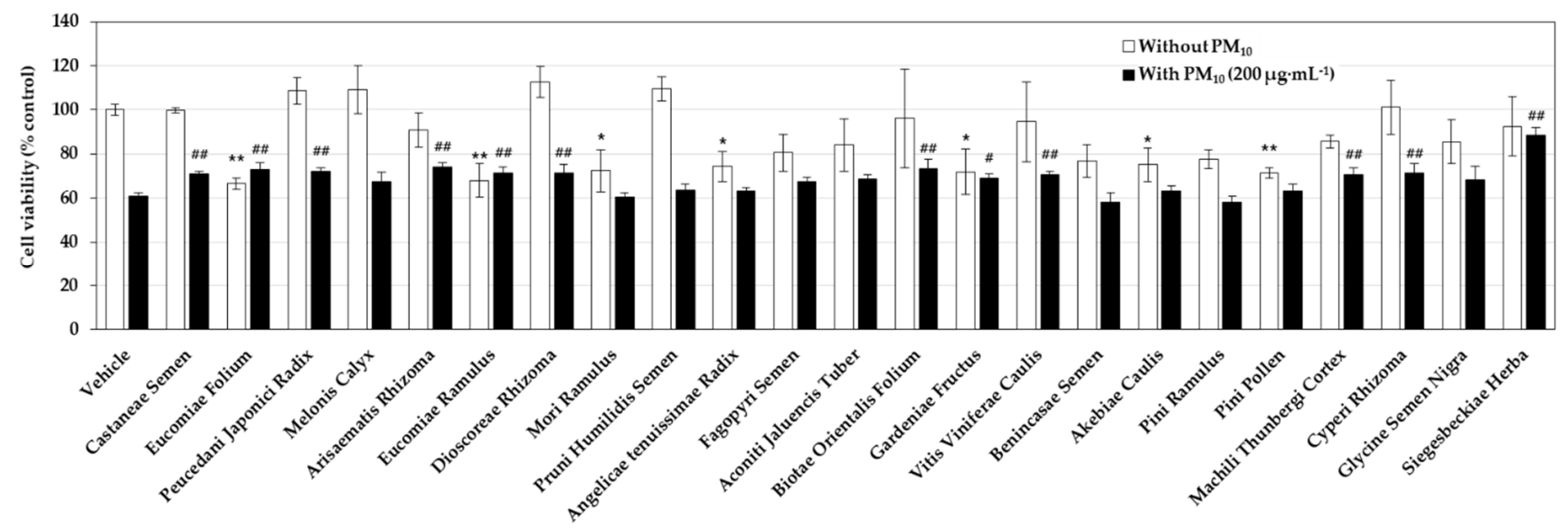

Figure 1. Effects of medicinal plant extracts on the viability of HaCaT keratinocytes cultured in the absence and presence of particulate matter with an approximate diameter of less than $10 \mu \mathrm{m}\left(\mathrm{PM}_{10}\right)$. Cells were pretreated with vehicle or each extract $\left(50 \mu \mathrm{g} \mathrm{mL}^{-1}\right)$ and cultured in the absence or presence of $\mathrm{PM}_{10}\left(200 \mu \mathrm{g} \mathrm{mL}^{-1}\right)$ for $48 \mathrm{~h}$. Cell viability was determined by the 3-(4,5-dimethylthiazol-2-yl)-2,5-diphenyl tetrazolium bromide (MTT) assay. Data are presented as mean \pm SD $(n=3)$. Statistical significance of intergroup differences was determined using one-way ANOVA followed by Dunnett's test. ${ }^{*} p<0.05$ and ${ }^{* *} p<0.01$ versus vehicle control; $\# p<0.05$ and $\# \# p<0.01$ versus $\mathrm{PM}_{10}$ only control.

\subsection{Effects of SHE on the Viability, LDH Release, Lipid Peroxidation, and ROS Production in $\mathrm{HaCaT}$ Cells Exposed to $\mathrm{PM}_{10}$}

SHE used in the preliminary experiment was purchased from an external plant extract bank. We also manufactured SHE from the dried leaves of Siegesbeckia pubescens Makino in our laboratory. Figure 2A,B shows the HPLC patterns of SHE purchased from an external plant extract bank and SHE prepared in our laboratory. The two extracts appeared to share several peaks with the same retention times, while the heights of these peaks were somewhat different. The effects of the two extracts on the viability of HaCaT cells in the presence or absence of $\mathrm{PM}_{10}$ exposure were compared in Figure $2 \mathrm{C}, \mathrm{D}$. Both extracts did not affect cell viability by themselves at the concentrations tested, and significantly increased the viability of cells exposed to $\mathrm{PM}_{10}$ to some degree. These results indicate that the phytochemical composition and biological activity of the two extracts are similar to each other. In subsequent experiments, SHE manufactured in our laboratory was used.

Figure $3 \mathrm{~A}, \mathrm{~B}$ shows the dose curves of $\mathrm{PM}_{10}$ and $\mathrm{SHE}$ on $\mathrm{HaCaT}$ cell viability. $\mathrm{PM}_{10}$ showed a gradual increase in toxicity up to $300 \mu \mathrm{g} \mathrm{mL} \mathrm{L}^{-1}$. In this study, $\mathrm{PM}_{10}$ was treated at $200 \mu \mathrm{g} \mathrm{mL}^{-1}$ as this concentration induced consistent and substantial cytotoxicity. SHE had no effect on the cell viability up to $100 \mu \mathrm{g} \mathrm{mL} \mathrm{L}^{-1}$ but reduced it at $200 \mu \mathrm{g} \cdot \mathrm{mL}^{-1}$. We selected the $\mathrm{PM}_{10}$ treatment concentration $\left(200 \mu \mathrm{g} \cdot \mathrm{mL}^{-1}\right)$ that showed sufficient toxicity for the experimental purpose, and the SHE treatment concentrations $\left(50 \mu \mathrm{g} \mathrm{mL}^{-1}\right.$ and $100 \mu \mathrm{g} \mathrm{mL}^{-1}$ ) were selected in the concentration range that did not reduce the cell viability. In Figure 3C-E, SHE treatment at $50 \mu \mathrm{g} \mathrm{mL}^{-1}$ and $100 \mu \mathrm{g} \mathrm{mL}^{-1}$ inhibited the decrease in cell viability, the increase in LDH release, and the increase in lipid peroxidation induced by $\mathrm{PM}_{10}$ treatment at $200 \mu \mathrm{g} \mathrm{mL}{ }^{-1}$. 
(A)

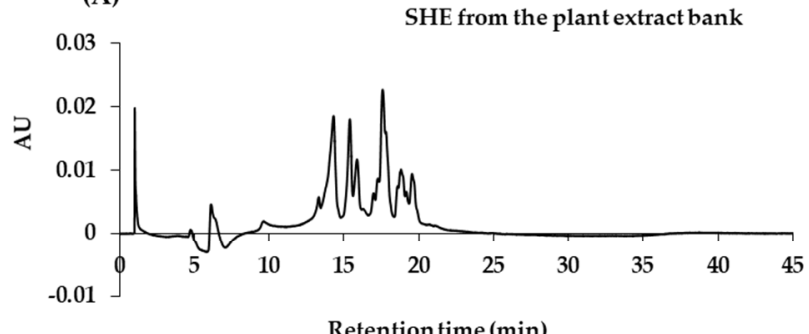

Retention time (min)

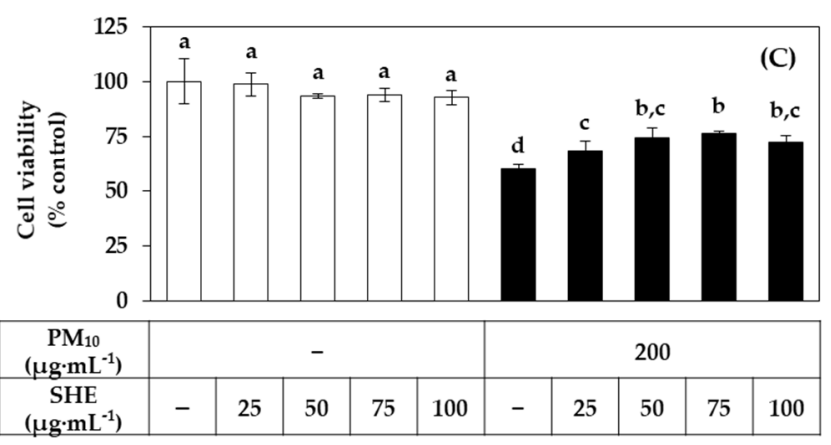

(B)

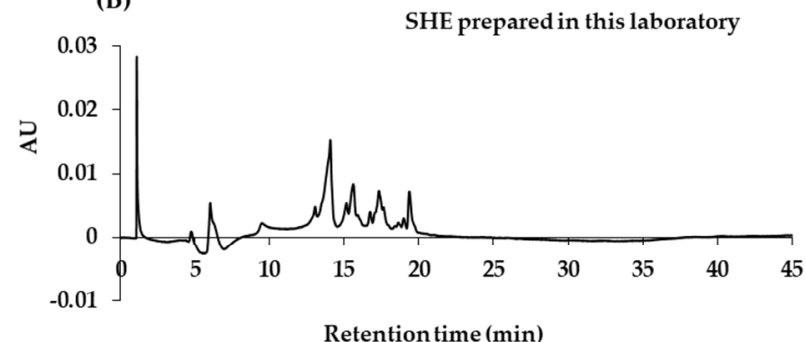

Retention time (min)

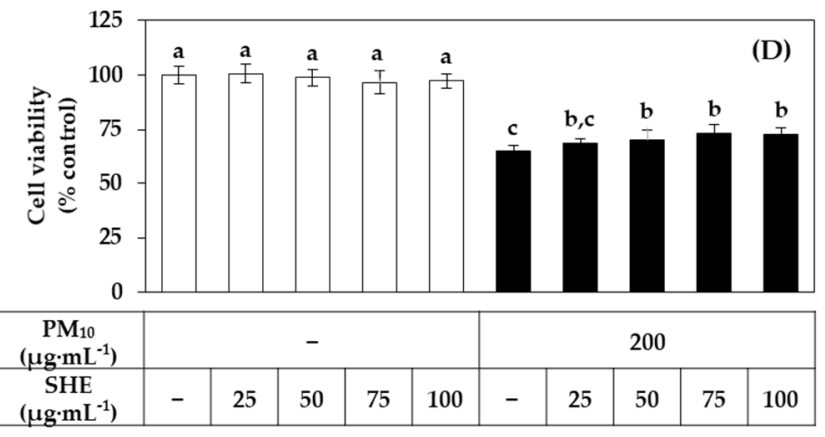

Figure 2. Comparison of Siegesbeckiae Herba extracts (SHEs) purchased from the plant extract bank and prepared in this laboratory. For the comparison of phytochemical composition, high-performance liquid chromatography (HPLC) profiles of the SHEs from the plant extract bank (A) and prepared in this laboratory (B) are shown (concentration $0.1 \%$ ). For the comparison of bioactivity, HaCaT keratinocytes were treated with SHEs from the plant extract bank (C) and prepared in this laboratory (D) at different concentrations and cultured in the absence or presence of $\mathrm{PM}_{10}(200 \mu \mathrm{g} \mathrm{mL}-1)$ for $48 \mathrm{~h}$. Cell viability was determined by the MTT assay. Data are presented as mean $\pm \operatorname{SD}(n=4)$. Duncan's multiple range test was performed to compare all group means to each other. Groups that share the same letters (a-d) do not have significantly different means at the $p<0.05$ level.
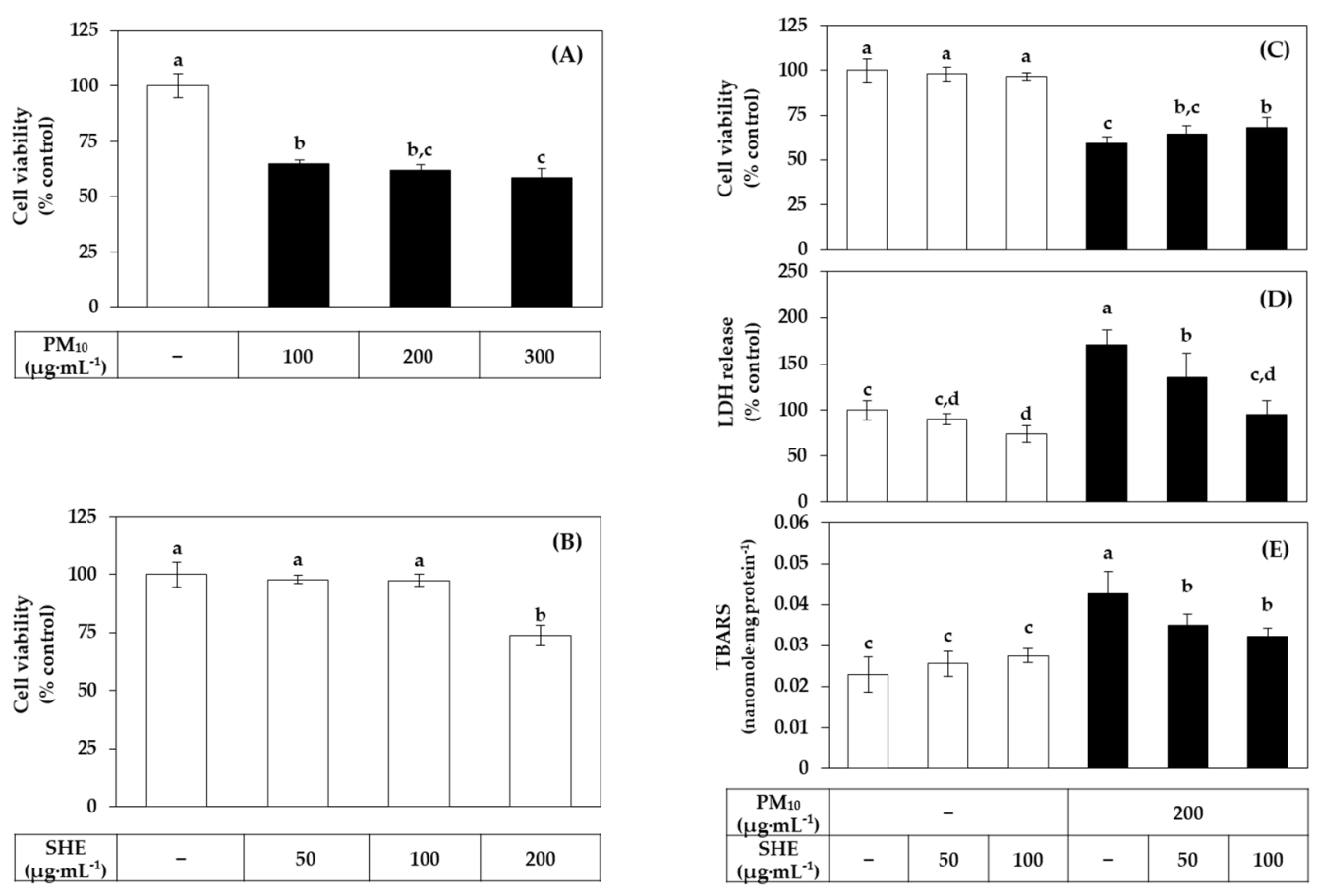

Figure 3. Effects of SHE on the viability, lactate dehydrogenase (LDH) release, and lipid peroxidation in HaCaT keratinocytes exposed to $\mathrm{PM}_{10}$. In (A,B), cells were treated with $\mathrm{PM}_{10}(\mathbf{A})$ or SHE (B) at different concentrations for $48 \mathrm{~h}$. In (C-E), cells were treated with SHE at different concentrations and cultured in the absence or presence of $\mathrm{PM}_{10}\left(200 \mu \mathrm{g} \mathrm{mL}{ }^{-1}\right)$ for $48 \mathrm{~h}$. Cell viability was determined by 
the MTT assay (A-C). LDH release was assessed using the conditioned medium (D). Lipid peroxidation of cell lysates was determined by the 2-thiobarbituric acid assay and data are presented as 2-thiobarbituric acid-reactive substance (TBARS) levels corrected for protein contents (E). Data are presented as mean $\pm \mathrm{SD}(n=5$ for $(\mathbf{A}-\mathbf{D}) ; n=4$ for $(\mathbf{E}))$. Duncan's multiple range test was performed to compare all group means to each other. Groups that share the same letters $(a-d)$ do not have significantly different means at the $p<0.05$ level.

Figure $4 \mathrm{~A}$ shows the $\mathrm{PM}_{10}$ dose and time-dependency of ROS production in HaCaT cells. In the following experiments, $\mathrm{PM}_{10}$ was treated at $200 \mu \mathrm{g} \mathrm{mL}{ }^{-1}$ for $60 \mathrm{~min}$ as this condition induced ROS production at a substantial level. ROS production was detected using DCFH-DA, a redox-sensitive dye that fluoresces after being oxidized by ROS. As shown in Figure 4B, SHE treatment at $50 \mu \mathrm{g} \mathrm{mL}^{-1}$ and $100 \mu \mathrm{g} \mathrm{mL}^{-1}$ inhibited the increase in ROS production induced by $\mathrm{PM}_{10}$ treatment at $200 \mu \mathrm{g} \mathrm{mL} \mathrm{m}^{-1}$ for $60 \mathrm{~min}$. Typical fluorescence pictures of cells treated differently are shown in Figure $4 \mathrm{C}$. The fluorescence due to the oxidation of DCFH-DA was increased by $\mathrm{PM}_{10}$ and the change was reduced by SHE.
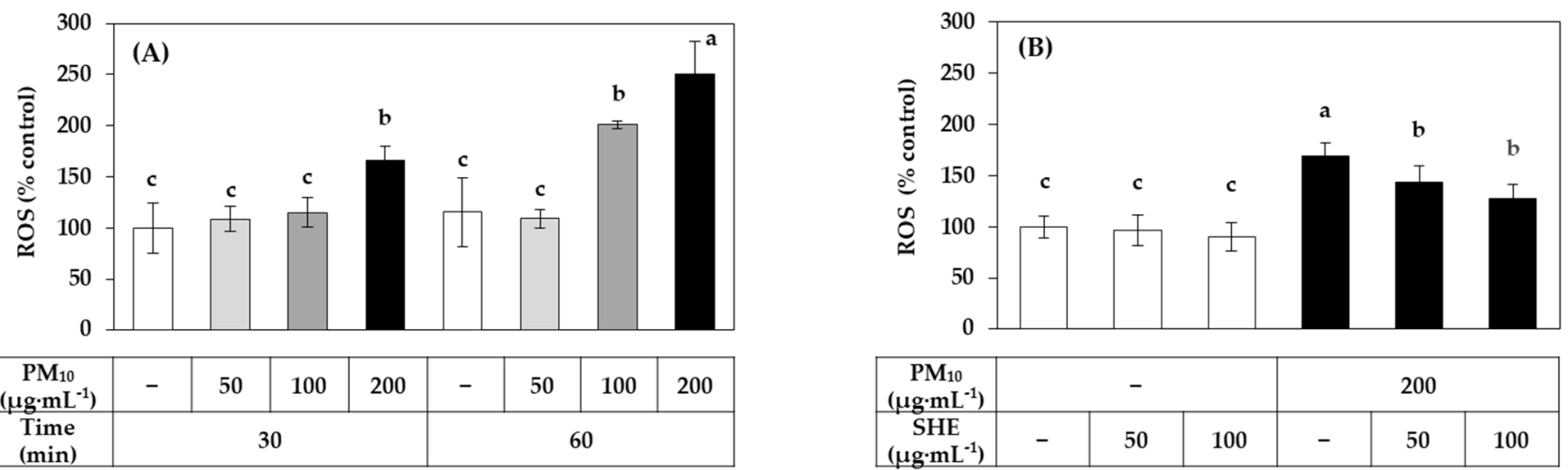

(C)
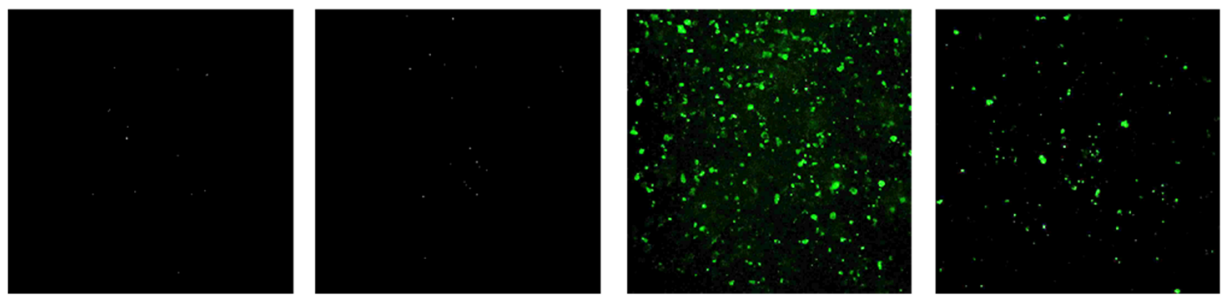

\begin{tabular}{|c|c|c|c|c|}
\hline $\begin{array}{c}\mathrm{PM}_{10} \\
\left(\mu \mathrm{g} \cdot \mathrm{mL}^{-1}\right)\end{array}$ & - & \multicolumn{2}{|c|}{200} \\
\hline $\begin{array}{c}\mathrm{SHE} \\
\left(\mu \mathrm{g} \cdot \mathrm{mL}^{-1}\right)\end{array}$ & - & 100 & - & 100 \\
\hline
\end{tabular}

Figure 4. Effects of SHE on the reactive oxygen species (ROS) production in HaCaT keratinocytes exposed to $\mathrm{PM}_{10}$. In (A), cells were labeled with $2^{\prime}, 7^{\prime}$-dichlorofluorescin diacetate (DCFH-DA) and exposed to $\mathrm{PM}_{10}$ at the indicated concentrations for $30 \mathrm{~min}$ or $60 \mathrm{~min}$. In (B,C), cells were labeled with DCFH-DA, treated with SHE at the indicated concentrations, and exposed to $\mathrm{PM}_{10}\left(200 \mu \mathrm{g} \mathrm{mL}{ }^{-1}\right)$ for $60 \mathrm{~min}$ or not. Typical images of cells fluorescing due to the oxidation of DCFH-DA by ROS are shown in $(\mathbf{C})$. The fluorescence of the cell extracts was measured to determine ROS levels $(\mathbf{A}, \mathbf{B})$. Data are presented as mean $\pm \mathrm{SD}(n=5$ for $(\mathbf{A})$ and $n=6$ for $(\mathbf{B})$ ). Duncan's multiple range test was performed to compare all group means to each other. Groups that share the same letters $(\mathrm{a}-\mathrm{c})$ do not have significantly different means at the $p<0.05$ level.

\subsection{Effects of SHE on the Expression of the Defense Genes in HaCaT Cells under Basal and $P M_{10}$-Exposed Conditions}

To gain insight into the mechanism of action of SHE to alleviate cellular oxidative damage, we examined the effect of SHE on the mRNA expression of several defense enzymes in HaCaT cells in the absence or presence of $\mathrm{PM}_{10}$ exposure, and the results 
are shown in Figure 5. SHE did not have a remarkable effect on the expression of NRF2, a master transcription factor that induces the expression of various genes in the body's antioxidant defense system, but decreased the expression of its negative regulator, KEAP1, both in the absence and presence of $\mathrm{PM}_{10}$ exposure. SHE further increased the mRNA expression of HMOX1 and NQO1, the main target genes of NRF2.

The mRNA expression of SOD1, which scavenges superoxide radicals, and CAT, which decomposes hydrogen peroxide, was not significantly affected by SHE. The mRNA expression of GPX1, which decomposes hydrogen peroxide or lipid peroxide, tended to be decreased by SHE, and that of GSTк1, which catalyzes GSH conjugation of xenobiotics, showed a tendency to slightly increase. The mRNA expression of GSR, which catalyzes the reduction of GSSG coupled with NADPH oxidation, was increased by SHE, and the mRNA expression of G6PDH, which supplies NADPH, was also significantly increased. In addition, the mRNA expressions of GCL-m and GCL-c acting at the rate-regulating step of GSH biosynthesis were increased by SHE. These results suggest that SHE enhances cellular antioxidant capacity, including synthesis and regeneration of GSH.
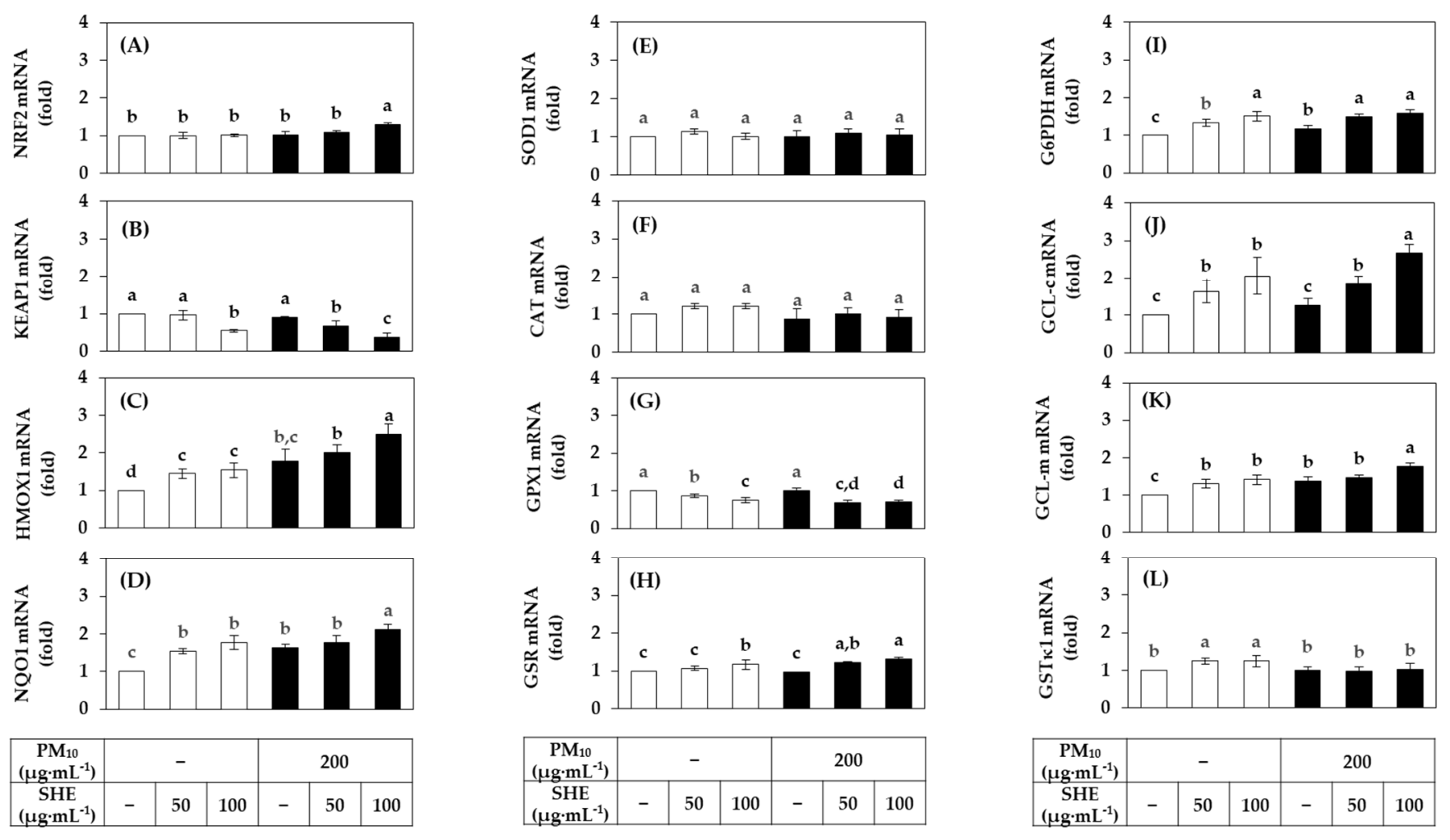

Figure 5. Effects of SHE on the mRNA expression levels of the defense genes in HaCaT keratinocytes under basal and $\mathrm{PM}_{10}$-exposed conditions. Cells were treated with SHE at different concentrations and cultured in the absence or presence of $\mathrm{PM}_{10}\left(200 \mu \mathrm{g} \mathrm{mL}^{-1}\right)$ for $24 \mathrm{~h}$. The mRNA levels of nuclear factor erythroid 2-related factor (NRF) 2 (A), kelch-like ECH-associated protein (KEAP) 1 (B), heme oxygenase (HMOX) 1 (C), NAD(P)H quinone oxidoreductase (NQO) 1 (D), superoxide dismutase (SOD) 1 (E), catalase (CAT) $($ F), glutathione peroxidase (GPX) $1(\mathrm{G})$, glutathione disulfide reductase (GSR) (H), glucose 6-phosphate dehydrogenase (G6PDH) (I), glutamate-cysteine ligase catalytic subunit (GCL-c) (J), glutamate-cysteine ligase modifier subunit (GCL-m) (K), and glutathione S-transferase (GST) k1 (L) were determined by quantitative real time-polymerase chain reaction (qRT-PCR) and normalized to that of glyceraldehyde 3-phosphate dehydrogenase $(\mathrm{GAPDH})$. Data are presented as mean $\pm \mathrm{SD}(n=3)$. Duncan's multiple range test was performed to compare all group means to each other. Groups that share the same letters (a, b, c, or d) do not have significantly different means at the $p<0.05$ level.

Western blot was performed to analyze the protein level of GCL-c, GCL-m and G6PDH as the representative proteins, and $\beta$-actin as a reference protein. As shown in Figure 6, SHE increased the protein levels of GCL-c and G6PDH in both the absence and presence 
of $\mathrm{PM}_{10}$. It also tended to increase the protein level of GCL-m although the differences were not statistically significant. The changes in the protein levels of these proteins were consistent with those in the mRNA levels observed above.
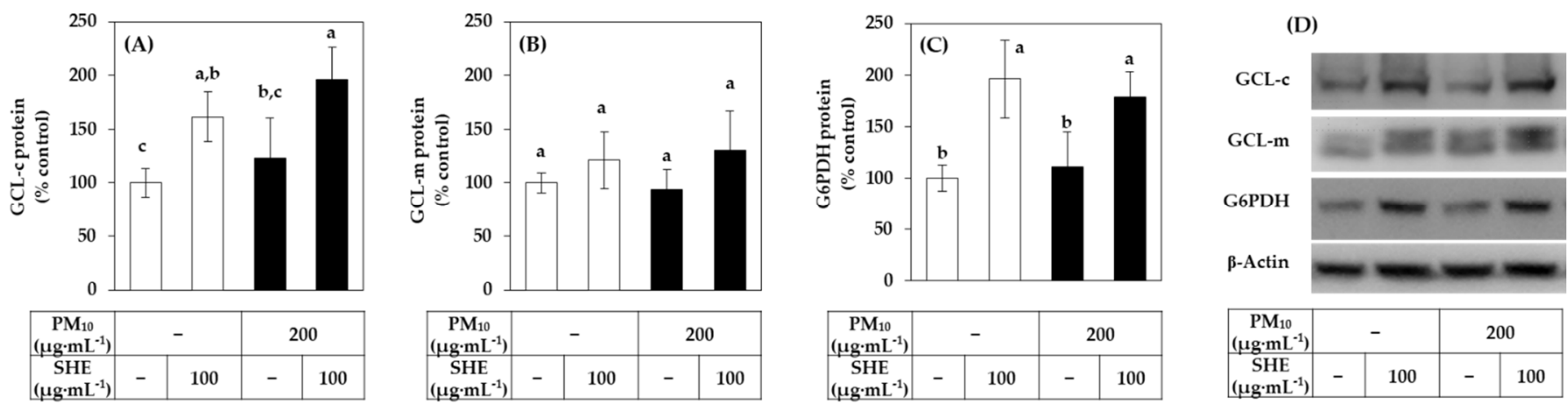

Figure 6. Effects of SHE on the protein levels of GCL-c, GCL-m, and G6PDH in HaCaT keratinocytes under basal and $\mathrm{PM}_{10}$-exposed conditions. Cells were treated with SHE $\left(100 \mu \mathrm{g} \mathrm{mL}^{-1}\right)$ and cultured in the absence or presence of PM 10 $\left(200 \mu \mathrm{g} \mathrm{mL}^{-1}\right)$ for $24 \mathrm{~h}$. The protein levels of GCL-c (A), GCL-m (B), and G6PDH (C) were determined by the Western blotting and normalized to that of $\beta$-actin. Representative blots are shown in (D). Data are presented as percentages of the control (mean $\pm \mathrm{SD}, n=3$ ). Duncan's multiple range test was performed to compare all group means to each other. Groups that share the same letters $(\mathrm{a}-\mathrm{c})$ do not have significantly different means at the $p<0.05$ level.

\subsection{Effects of SHE on the GSH and GSSG Levels in HaCaT Cells Exposed to PM $M_{10}$}

The effect of SHE on the contents of GSH and its oxidized form, GSSG, in cells was investigated. As shown in Figure 7, SHE increased the GSH content in both the absence and presence of $\mathrm{PM}_{10}$. $\mathrm{PM}_{10}$ did not significantly affect the level of $\mathrm{GSH}$, but significantly increased the level of GSSG. As a result, the total GSH plus GSSG content increased by SHE in a concentration-dependent manner. Interestingly, the proportion of GSSG in the total GSH and GSSG content was greatly increased by $\mathrm{PM}_{10}$ and this change was attenuated by SHE. This suggests that $\mathrm{SHE}$ enhances cell resistance to $\mathrm{PM}_{10}$-induced oxidative stress by increasing the synthesis of GSH in cells.
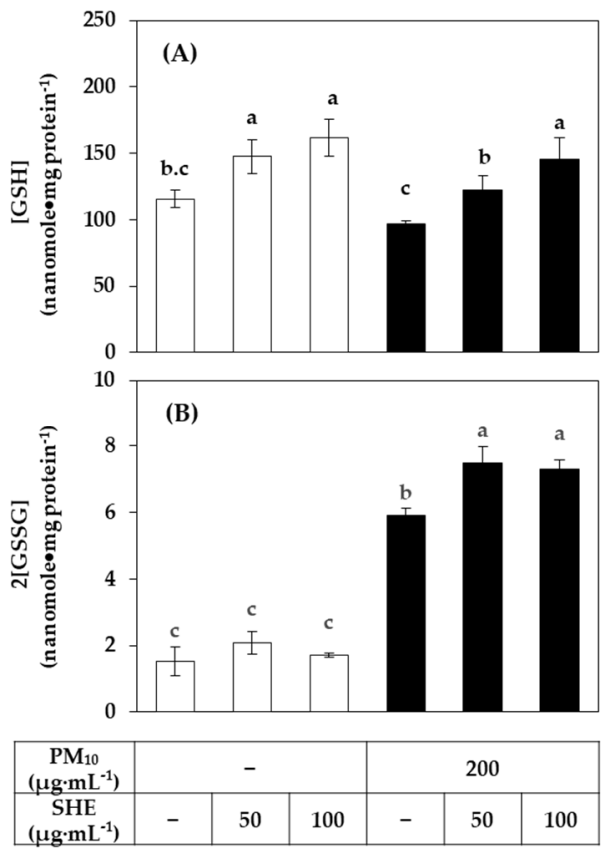
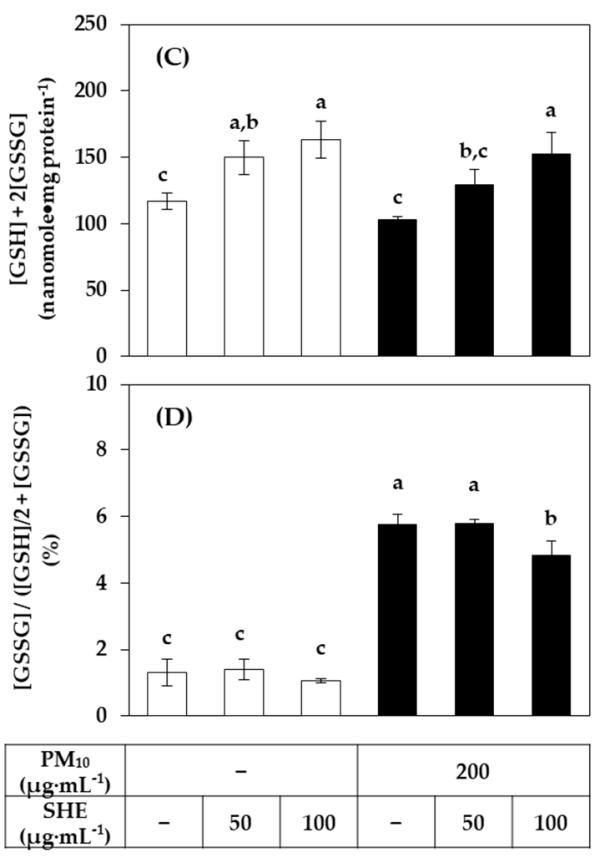

Figure 7. Effects of SHE on the contents of reduced glutathione (GSH) and its oxidized form, glutathione disulfide (GSSG) in HaCaT keratinocytes exposed to $\mathrm{PM}_{10}$. Cells were treated with SHE 
at different concentrations and cultured in the absence or presence of $\mathrm{PM}_{10}\left(200 \mu \mathrm{g} \mathrm{mL}^{-1}\right)$ for $24 \mathrm{~h}$. The GSH contents (A) were calculated by subtracting the GSSG contents (B) from the total GSH plus GSSG contents (C). The relative ratios of GSSG contents to the total GSH plus GSSG contents were presented in (D). Data are presented as mean \pm SD $(n=3)$. Duncan's multiple range test was performed to compare all group means to each other. Groups that share the same letters $(\mathrm{a}-\mathrm{c})$ do not have significantly different means at the $p<0.05$ level.

\subsection{Effects of Solvent Fractions of SHE on the Viability of HaCaT Cells Exposed to PM10}

To investigate which phytochemicals contained in SHE alleviate the cytotoxicity of $\mathrm{PM}_{10}$, this extract was divided into several solvent fractions, namely, MC, EA, BA, and WT fractions according to the method illustrated in Figure 8A. Additionally, the effect of each fraction on the viability of $\mathrm{HaCaT}$ cells under $\mathrm{PM}_{10}$ exposure or non-exposure conditions was comparatively evaluated. As shown in Figure 8B, the MC fraction itself showed severe cytotoxicity. Although the EA fraction and WT fraction had weaker cytotoxicity, they did not alleviate $\mathrm{PM}_{10}$ cytotoxicity. Notably, the BA fraction increased the cell viability compared to the vehicle control in both the absence and presence of $\mathrm{PM}_{10}$.

(A)

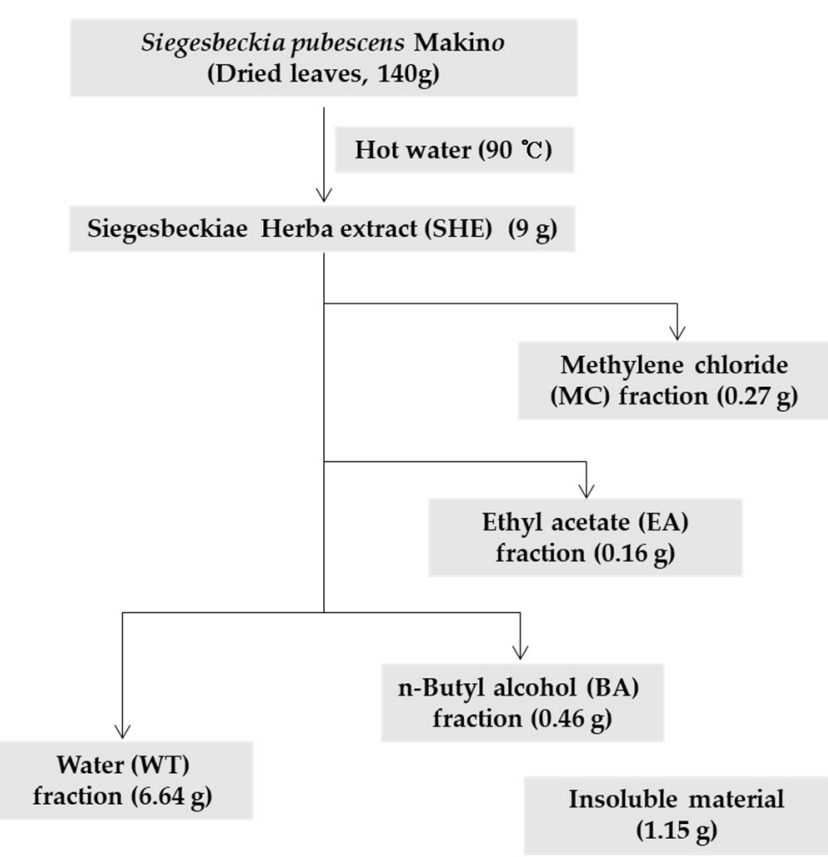

(B)

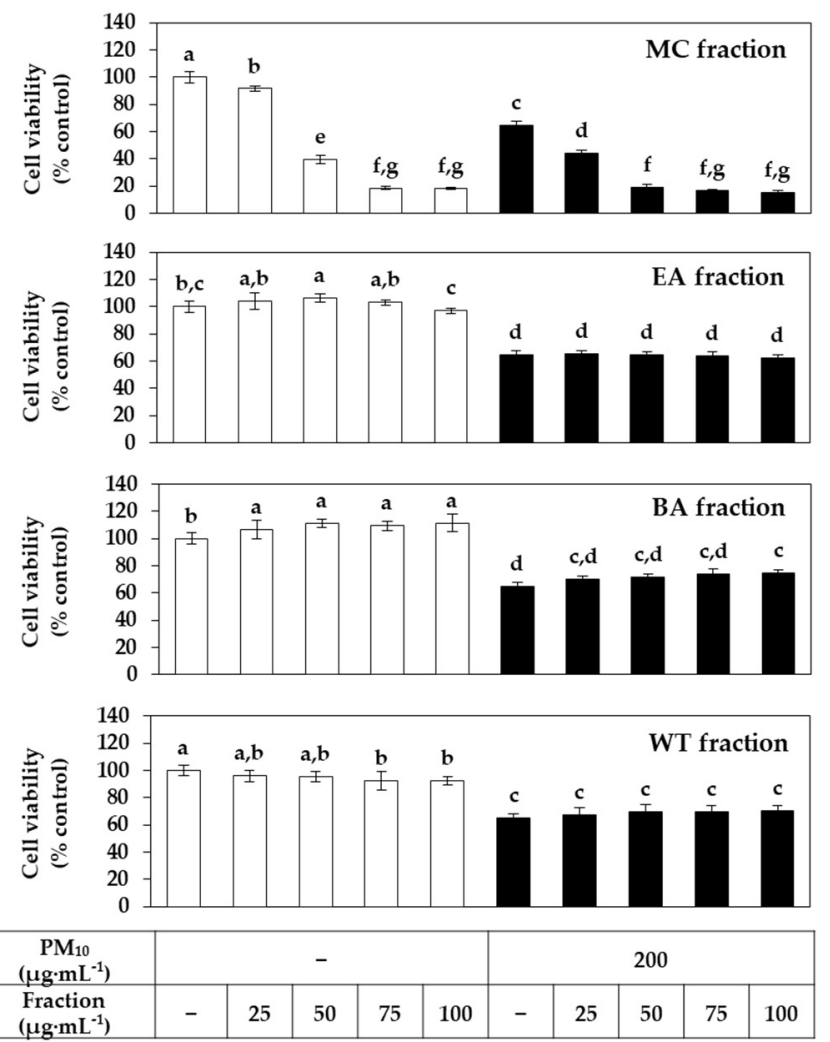

Figure 8. Effects of various solvent fractions of SHE on the viability in HaCaT keratinocytes exposed to PM 10 . (A) SHE was separated into methylene chloride (MC), ethyl acetate (EA), n-butyl alcohol (BA), and water (WT) fractions. (B) Cells were treated with each solvent fraction at different concentrations and cultured in the absence or presence of $\mathrm{PM}_{10}\left(200 \mu \mathrm{g} \mathrm{mL}{ }^{-1}\right)$ for $48 \mathrm{~h}$. Cell viability was determined by the MTT assay. Data are presented as mean \pm SD $(n=4)$. Duncan's multiple range test was performed to compare all group means to each other. Groups that share the same letters (a-g) do not have significantly different means at the $p<0.05$ level.

\subsection{HPLC-DAD Analysis of Solvent Fractions of SHE}

HPLC-DAD analysis was performed on SHE and its MC, EA, BA, and WT fractions. As shown in Figure 9, it was shown that the BA fraction contained chlorogenic acid and the EA fraction contained caffeic acid. This was based on a comparison of retention times and absorption spectra of the specified peaks with standard materials. 
(A)

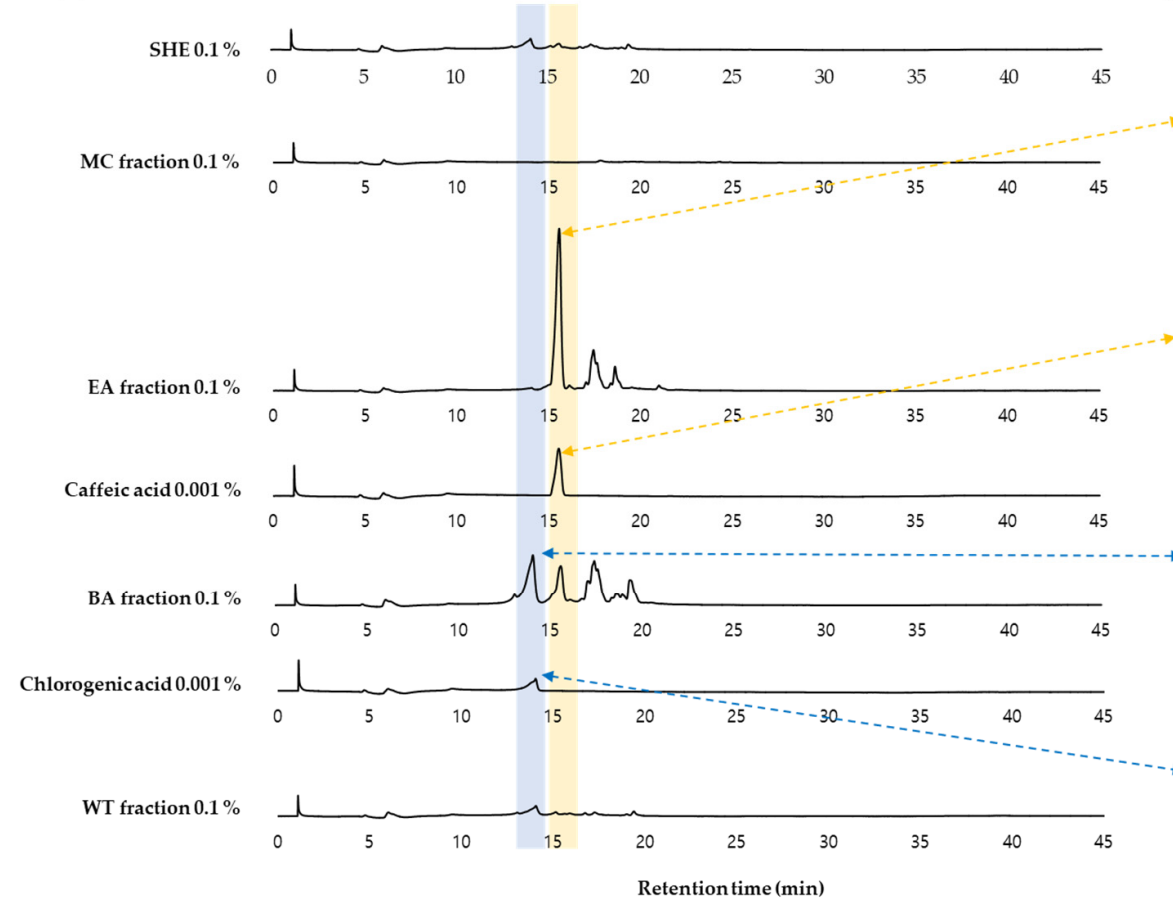

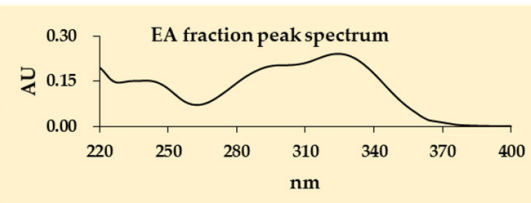
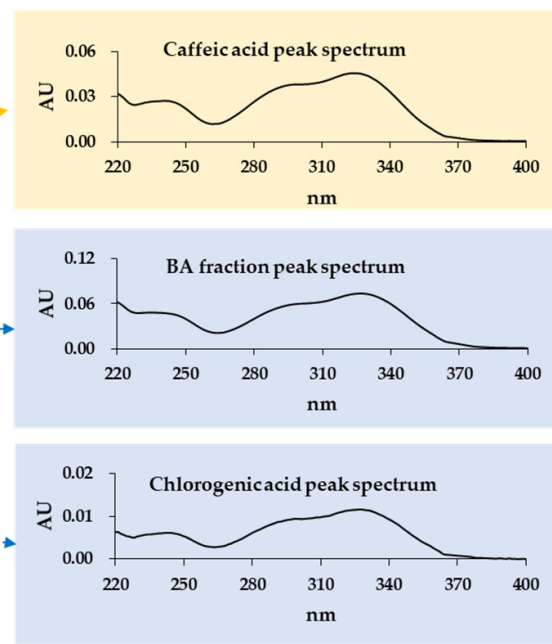

Figure 9. High-performance liquid chromatography-photodiode array detection (HPLC-DAD) analysis of SHE and its solvent fractions. SHE was separated into MC, EA, BA, and WT fractions. HPLC-DAD analysis conditions are described in Materials and Methods. Authentic chlorogenic acid and caffeic acid were used to identify the major peaks by comparing retention times and spectra. Chromatograms detected at $330 \mathrm{~nm}$ are shown in (A). UV absorption spectra of the indicated peaks are shown in (B).

3.7. Effects of Chlorogenic Acid vs. Caffeic Acid on the Viability, LDH Release, and ROS Production of $\mathrm{HaCaT}$ Cells Exposed to $\mathrm{PM}_{10}$

Chlorogenic acid is a compound of caffeic acid and quinic acid (Figure 10A,B). In the following experiments, we comparatively evaluated the effects of these two phytochemicals on the viability and ROS production of $\mathrm{HaCaT}$ cells under $\mathrm{PM}_{10}$ exposure or non-exposure conditions. As shown in Figure 10C, chlorogenic acid increased the cell viability compared to the vehicle control in both the presence and absence of $\mathrm{PM}_{10}$. However, this action was not observed with caffeic acid (Figure 10D).

The activity of inhibiting $\mathrm{PM}_{10}$-induced $\mathrm{LDH}$ release was found to be relatively superior with chlorogenic acid compared to caffeic acid (Figure 10E,F).

Figure 11A,B shows the inhibitory effects of chlorogenic acid and caffeic acid on the ROS production induced by $\mathrm{PM}_{10}$. Among these two compounds, chlorogenic acid showed a stronger inhibitory effect against $\mathrm{PM}_{10}$-induced ROS production. Typical fluorescence pictures of cells are shown in Figure 11C. The fluorescence due to the oxidation of DCFHDA by ROS was increased by $\mathrm{PM}_{10}$ and the change was reduced by chlorogenic acid more effectively than caffeic acid. 
(A)

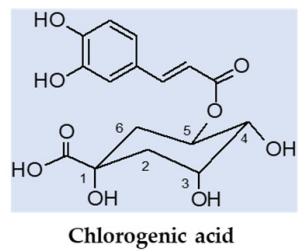<smiles>O=C(O)/C=C/c1ccc(O)c(O)c1</smiles>
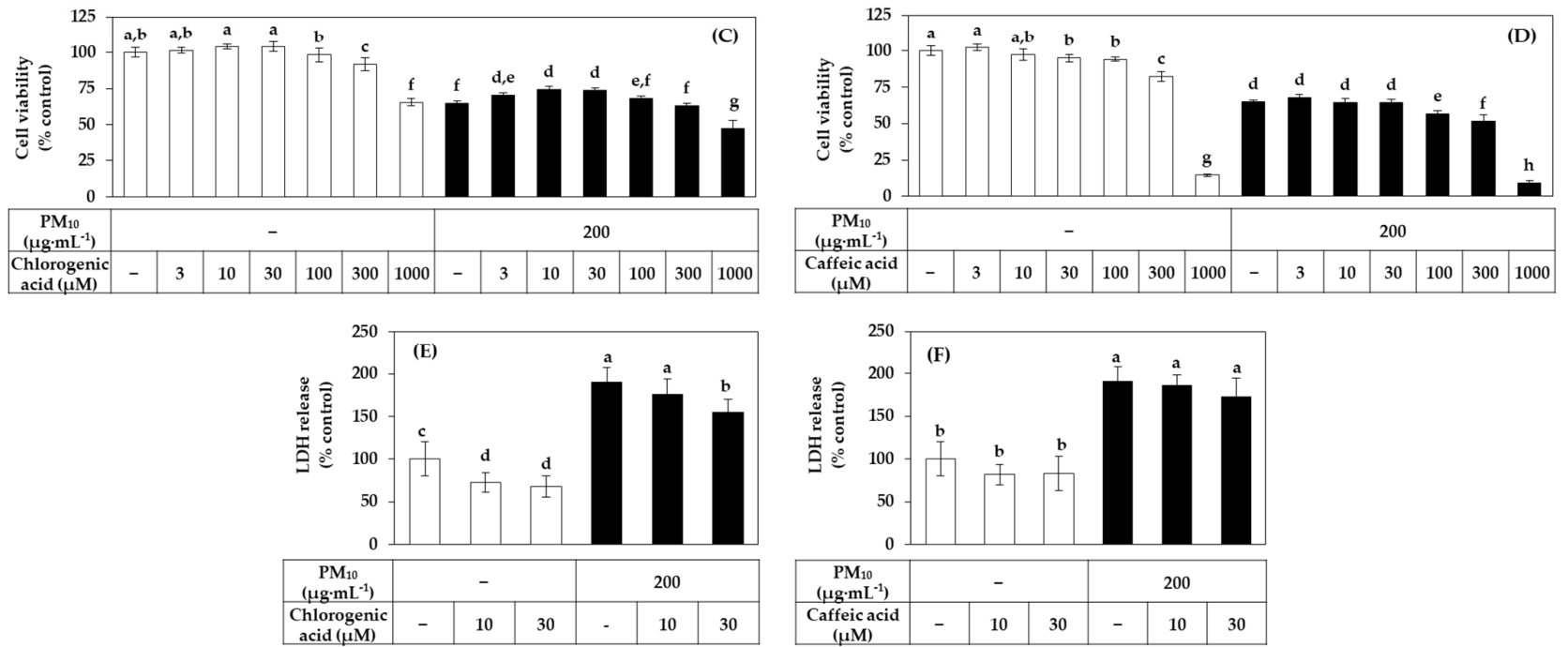

Figure 10. Effects of chlorogenic acid versus caffeic acid on the viability and LDH release of HaCaT keratinocytes exposed to $\mathrm{PM}_{10}$. The chemical structures of chlorogenic acid and caffeic acid are shown in $(\mathbf{A}, \mathbf{B})$. In $(\mathbf{C}-\mathbf{F})$, cells were treated with chlorogenic acid (C) or caffeic acid (D) at the specified concentrations and incubated in the absence or presence of $\mathrm{PM}_{10}\left(200 \mu \mathrm{g} \mathrm{mL} \mathrm{m}^{-1}\right)$ for 48 h. Cell viability was determined by the MTT assay $(\mathbf{C}, \mathbf{D})$. LDH release was assessed using the conditioned medium $(\mathbf{E}, \mathbf{F})$. Data are presented as mean $\pm \mathrm{SD}(n=4$ for $(\mathbf{C}, \mathbf{D}) ; n=5$ for $(\mathbf{E}, \mathbf{F}))$. Duncan's multiple range test was performed to compare all group means to each other. Groups that share the same letters $(a-h)$ do not have significantly different means at the $p<0.05$ level.
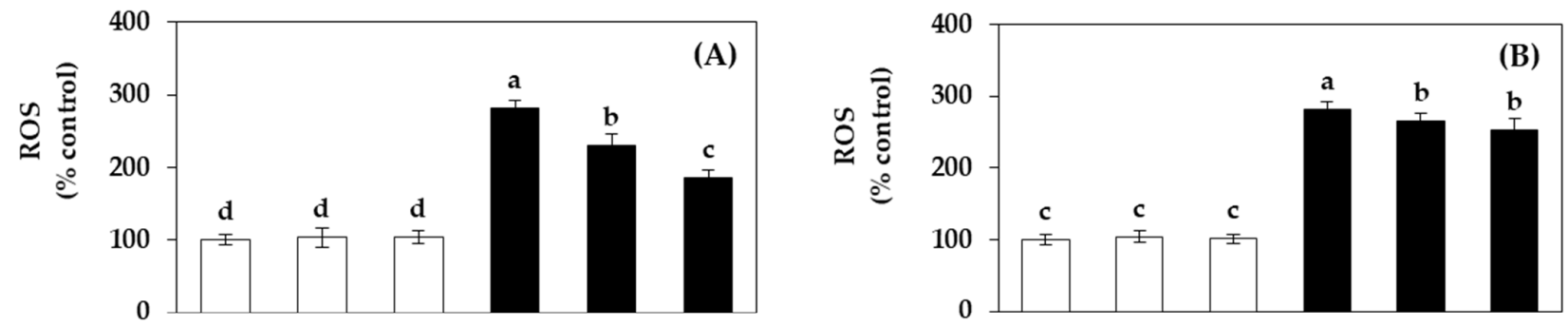

\begin{tabular}{|c|c|c|c|c|c|c|}
\hline $\begin{array}{c}\mathrm{PM}_{10} \\
\left(\mu \mathrm{g} \cdot \mathrm{mL}^{-1}\right)\end{array}$ & \multicolumn{3}{|c|}{-} & \multicolumn{3}{c|}{200} \\
\hline $\begin{array}{c}\text { Chlorogenic } \\
\text { acid }(\mu \mathrm{M})\end{array}$ & - & 10 & 30 & - & 10 & 30 \\
\hline
\end{tabular}

\begin{tabular}{|c|c|c|c|c|c|c|}
\hline $\begin{array}{c}\mathrm{PM}_{10} \\
\left(\mu \mathrm{g} \cdot \mathrm{mL}^{-1}\right)\end{array}$ & \multicolumn{3}{|c|}{-} & \multicolumn{3}{c|}{200} \\
\hline $\begin{array}{c}\text { Caffeic acid } \\
(\mu \mathrm{M})\end{array}$ & - & 10 & 30 & - & 10 & 30 \\
\hline
\end{tabular}

(C)
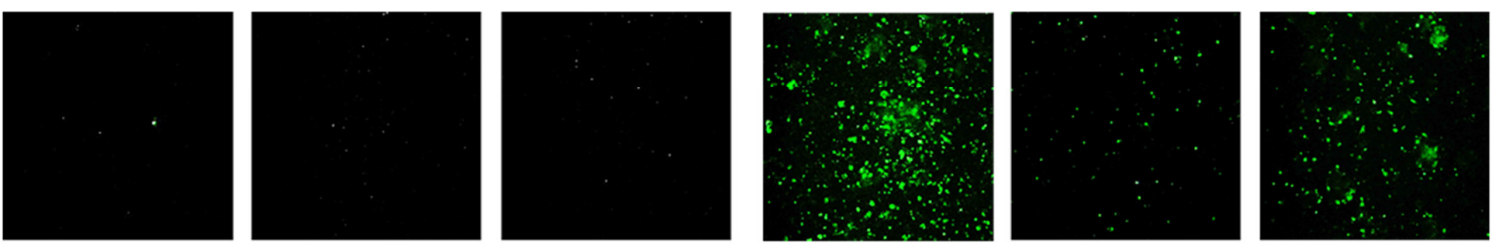

\begin{tabular}{|c|c|c|c|c|c|c|}
\hline $\begin{array}{c}\mathrm{PM}_{10} \\
\left(\mu \mathrm{g} \cdot \mathrm{mL}^{-1}\right)\end{array}$ & \multicolumn{3}{|c|}{-} & \multicolumn{3}{|c|}{200} \\
& - & $\begin{array}{c}\text { Chlorogenicacid } \\
(30 \mu \mathrm{M})\end{array}$ & $\begin{array}{c}\text { Caffeic acid } \\
(30 \mu \mathrm{M})\end{array}$ & - & $\begin{array}{c}\text { Chlorogenic acid } \\
(30 \mu \mathrm{M})\end{array}$ & $\begin{array}{c}\text { Caffeic acid } \\
(30 \mu \mathrm{M})\end{array}$ \\
\cline { 2 - 6 }
\end{tabular}

Figure 11. Effects of chlorogenic acid versus caffeic acid on the ROS production in HaCaT keratinocytes exposed to PM 10 . 
Cells were labeled with DCFH-DA, treated with SHE at different concentrations, and exposed to $\mathrm{PM}_{10}\left(200 \mu \mathrm{g} \mathrm{mL}^{-1}\right)$ for $60 \mathrm{~min}$ or not. Typical images of cells fluorescing due to the oxidation of DCFH-DA by ROS are shown in (C). The fluorescence of the cell extracts was measured to determine ROS levels (A,B). Data are presented as mean $\pm \operatorname{SD}(n=4)$. Duncan's multiple range test was performed to compare all group means to each other. Groups that share the same letters (a-d) do not have significantly different means at the $p<0.05$ level.

\section{Discussion}

This study demonstrated that SHE is a useful plant extract to alleviate $\mathrm{PM}_{10}$-induced death of $\mathrm{HaCaT}$ cells. $\mathrm{PM}_{10}$ increased ROS production and lipid peroxidation in $\mathrm{HaCaT}$ cells, and these changes were moderated by SHE in a dose-dependent manner. It is suggested that SHE enhances antioxidant capacity by increasing the expression of defense genes in cells (Figure 12).

Enzymes such as SOD1, CAT, and GPX1 expressed in cells have the activity to directly remove $\mathrm{O}_{2}{ }^{\bullet-}, \mathrm{H}_{2} \mathrm{O}_{2}$, and lipid peroxide [48]. $\mathrm{GSH}$ is a tripeptide that plays an important role in maintaining the redox balance of cells, which is used as a substrate in enzymatic reactions mediated by GPX1 and GST 1 1 and acts as a direct antioxidant [49]. GSR and G6PDH expressed in cells are involved in the regeneration of GSH [50,51], and GCL-c and GCL-m are involved in the synthesis of GSH $[49,52]$. The results of this study showed that SHE increased the expression of GSTk1, GSR, G6PDH, GCL-c, and GCL-m rather than the expression of SOD1, CAT, and GPX1. This suggests that SHE selectively induces enzymes involved in the synthesis of GSH through glutamate-cysteine, the regeneration of GSH from GSSG, and GSH conjugation of xenobiotics, rather than enzymes involved in direct scavenging of ROS. Consistently, SHE increased the content of GSH and mitigated the increase in GSSG caused by $\mathrm{PM}_{10}$.

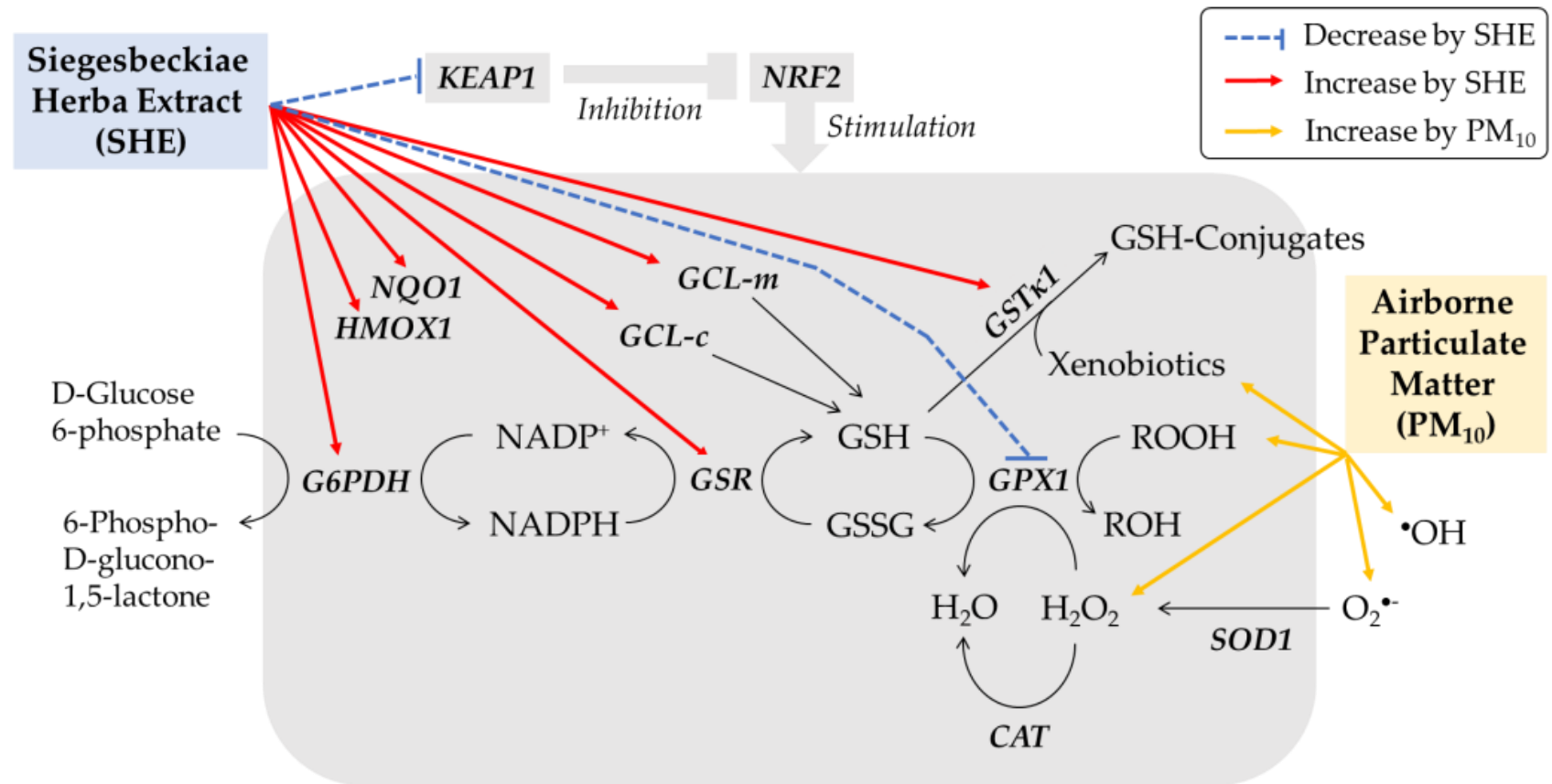

Figure 12. Working model for the protective effects of SHE against $\mathrm{PM}_{10}$-induced oxidative stress in HaCaT keratinocytes. $\mathrm{PM}_{10}$ increases ROS, such as superoxide radical $\left(\mathrm{O}_{2}{ }^{\bullet-}\right)$, hydrogen peroxide $\left(\mathrm{H}_{2} \mathrm{O}_{2}\right)$, and hydroxyl radical $\left({ }^{\bullet} \mathrm{OH}\right)$, and lipid peroxide $(\mathrm{ROOH})$, causing oxidative stress and death of HaCaT cells. SHE does not change the mRNA expression of NRF2, but decreases that of KEAP1, a negative regulator of NRF2, leading to the activation of NRF2 to induce the expression of target genes, such as HMOX1 and NQO1. SHE selectively induces the enzymes involved in the synthesis of GSH (GCL-C and GCL-m), the regeneration of GSH (GSR and G6PDH), and GSH conjugation of xenobiotics (GSTk1), rather than the enzymes that directly scavenge ROS (SOD1, CAT, and GPX1). SHE increases the cellular content of GSH and mitigates the oxidation of GSH to GSSG caused by $\mathrm{PM}_{10}$. 
NRF2 is a transcription factor that induces the expression of phase II metabolism/ antioxidant enzymes and plays an important function in regulating the body's defense mechanisms $[53,54]$. Activation of this transcription factor is regulated by various mechanisms, and KEAP1 is one of its negative regulators [55]. Upon binding to KEAP1, NRF2 is excluded from the nucleus and degraded in the proteasome. On the other hand, when NRF2 is separated from KEAP1 by a certain stimulus, the free NRF2 enters the nucleus and can bind to the antioxidant response element (ARE) of the promoter of the target gene together with various other factors. This transactivates the expression of several genes, such as HMOX1, NQO1, GCL-c, GCL-m, and GSTk1. In this study, SHE did not change the expression of NRF2 but decreased the expression of KEAP1. SHE increased the expression of target genes, such as HMOX1 and NQO1. This suggests that SHE activated the NRF2 system in cells.

As plant-derived substances can have positive or negative effects on cell physiology [24-27], it is important to select safe and effective types and to select their optimal concentration for use. The plant extracts tested in this study showed different or opposite effects on cell viability in the absence and presence of $\mathrm{PM}_{10}$. Among them, SHE was selected as a plant extract that safely and effectively alleviates the cytotoxicity of $\mathrm{PM}_{10}$. SHE is a mixture of various substances, and therefore the observed results are the combined effects of several components. Interesting results were obtained by comparing the effects of different solvent fractions of SHE. That is, among the solvent fractions of SHE, the BA fraction increased the cell viability whereas the MC fraction decreased the cell viability, and the other two fractions had no significant effect. The BA fraction contained a high amount of chlorogenic acid whereas the EA fraction contained a high amount of caffeic acid. Thus, we could predict that chlorogenic acid contained in the BA fraction might be an active ingredient that provided cytoprotective effects against $\mathrm{PM}_{10}$ toxicity. Consistently with this notion, chlorogenic acid ameliorated the death of $\mathrm{HaCaT}$ cells exposed to $\mathrm{PM}_{10}$ and reduced $\mathrm{PM}_{10}$-induced cellular ROS production more effectively than caffeic acid. In this study, about $100 \mu \mathrm{g} \mathrm{mL} \mathrm{mL}^{-1}$ of SHE and $30 \mu \mathrm{M}\left(10.6 \mu \mathrm{g} \cdot \mathrm{mL}^{-1}\right)$ of chlorogenic acid were selected as the optimal concentrations to use with high safety and cell protection efficacy.

It was previously reported that chlorogenic acid reduced oxidative stress by activating the NRF2 pathway in various in vitro and in vivo models [56-58]. Therefore, when combined with the results of our current study, SHE containing chlorogenic acid is suggested to mitigate $\mathrm{PM}_{10}$ cytotoxicity by activating the NRF2 pathway.

SHE derived from Siegesbeckia pubescens exhibits anti-inflammatory and wound healing properties in various in vitro and in vivo models [59-61]. Several terpenoids and phenolic compounds have been proposed as active ingredients that provide anti-inflammatory action [62-64]. Furthermore, 5,3'-dihydroxy-3,7,4'-trimethoxyflavone isolated from Siegesbeckia pubescens was shown to exert cytoprotective and neuroinflammatory activities in cells by involving HMOX1 induction [65]. However, there was no previous study on the cytoprotective effect of SHE derived from Siegesbeckia pubescens against PM toxicity. Meanwhile, an extract of tart cherry (Prunus cerasus L.) containing chlorogenic acid, quercetin, and kaempferol was reported to inhibit the production of ROS and the expression of apoptosis-related genes in $\mathrm{HaCaT}$ keratinocytes exposed to $\mathrm{PM}_{10}$ [66]. However, no specific experimental results were provided for chlorogenic acid itself. Therefore, our present study is the first to report the protective effect of SHE and chlorogenic acid against $\mathrm{PM}_{10}$.

In this study, the MTT assay was used to measure cell viability. Since particles and redox-sensitive substances can interfere with the MTT assay [67-69], the cells had been carefully washed with PBS to remove interfering materials before the assay. In addition, cell damage was also evaluated using the LDH release assay.

DCFH-DA was used as a fluorescent probe for measuring intracellular ROS production. Because the black pigment of $\mathrm{PM}_{10}$ interferes with the accurate measurement of low levels of fluorescence generated from the cells, we used a method of collecting cells from 12-well culture plates, extracting with a small volume $(150 \mu \mathrm{L})$ of lysis buffer, centrifuging to remove the insoluble precipitate, and measuring the fluorescence of the extract, instead of 
directly measuring the fluorescence of the attached cells. For complementary purposes, fluorescence images of cells were additionally presented.

Immortalized HaCaT keratinocytes were used in this study and it is necessary to confirm the main findings of this study using normal human epidermal keratinocytes, 3-dimensional skin models, and in vivo animal models. It is also important to examine whether the phytochemicals have the same or different outcomes in transformed and normal cells in future studies.

\section{Conclusions}

In conclusion, the results of this study suggest that SHE derived from Siegesbeckia pubescens can increase the cellular antioxidant capacity through induction of defense genes, such as GCL-c, GCL-m, and G6PDH, and mitigate oxidative stress and enhance cell viability under $\mathrm{PM}_{10}$-exposed conditions. It is also suggested that chlorogenic acid enriched in the BA fraction of SHE may be the active phytochemical of SHE providing such antioxidant and cytoprotective effects.

Author Contributions: Investigation, J.W.H. and Y.C.B.; writing, J.W.H. and Y.C.B.; conceptualization, supervision and funding acquisition, Y.C.B. All authors have read and agreed to the published version of the manuscript.

Funding: This research was supported by a grant of the Korea Health Technology R\&D Project through the Korea Health Industry Development Institute (KHIDI), funded by the Ministry of Health and Welfare, Republic of Korea (grant number: HP20C0004).

Institutional Review Board Statement: Not applicable.

Informed Consent Statement: Not applicable.

Data Availability Statement: The data presented in this study are available in this manuscript.

Conflicts of Interest: The authors declare no conflict of interest.

\section{Abbreviations}

$\begin{array}{ll}\text { ARE } & \text { antioxidant response element } \\ \text { BA } & \text { n-butyl alcohol } \\ \text { CAT } & \text { catalase } \\ \text { DCFH-DA } & 2^{\prime}, 7^{\prime} \text {-dichlorodihydrofluorescein diacetate } \\ \text { DTNB } & \text { 5,5-dithio-bis-2-nitrobenzoic acid } \\ \text { EA } & \text { ethyl acetate } \\ \text { G6PDH } & \text { glucose 6-phosphate dehydrogenase } \\ \text { GAPDH } & \text { glyceraldehyde 3-phosphate dehydrogenase } \\ \text { GCL-c } & \text { glutamate-cysteine ligase catalytic subunit } \\ \text { GCL-m } & \text { glutamate-cysteine ligase modifier subunit } \\ \text { GPX } & \text { glutathione peroxidase } \\ \text { GSH } & \text { glutathione } \\ \text { GSR } & \text { glutathione disulfide reductase } \\ \text { GSSG } & \text { glutathione disulfide } \\ \text { GST } & \text { glutathione S-transferase } \\ \text { HMOX } & \text { heme oxygenase } \\ \text { HPLC-DAD } & \text { high-performance liquid chromatography-photodiode array detection } \\ \text { IL } & \text { interleukin } \\ \text { KEAP } & \text { kelch-like ECH-associated protein } \\ \text { LDH } & \text { lactate dehydrogenase } \\ \text { MC } & \text { methylene chloride } \\ \text { MMP } & \text { matrix metalloproteinase } \\ \text { MTT } & \text { 3-[4,5-dimethylthiazol-2-yl]-2,5-diphenyl tetrazolium bromide } \\ \text { NQO } & \text { NAD(P)H quinone oxidoreductase } \\ \text { NRF } & \text { nuclear factor erythroid 2-related factor } \\ & \end{array}$




$\begin{array}{ll}\text { PBS } & \text { phosphate-buffered saline } \\ \text { PM } & \text { particulate matter } \\ \text { qRT-PCR } & \text { quantitative reverse transcriptase-polymerase chain reaction } \\ \text { ROS } & \text { reactive oxygen species } \\ \text { SHE } & \text { Siegesbeckiae Herba extract } \\ \text { SOD } & \text { superoxide dismutase } \\ \text { TBA } & \text { 2-thiobarbituric acid } \\ \text { TBARS } & \text { 2-thiobarbituric acid-reactive substance } \\ \text { WT } & \text { water }\end{array}$

\section{References}

1. Mukherjee, A.; Agrawal, M. World air particulate matter: Sources, distribution and health effects. Environ. Chem. Lett. 2017, 15, 283-309. [CrossRef]

2. Fuzzi, S.; Baltensperger, U.; Carslaw, K.; Decesari, S.; Van Der Gon, H.D.; Facchini, M.C.; Fowler, D.; Koren, I.; Langford, B.; Lohmann, U.; et al. Particulate matter, air quality and climate: Lessons learned and future needs. Atmos. Chem. Phys. Discuss. 2015, 15, 8217-8299. [CrossRef]

3. Ngoc, L.T.N.; Park, D.; Lee, Y.; Lee, Y.-C. Systematic Review and Meta-Analysis of Human Skin Diseases Due to Particulate Matter. Int. J. Environ. Res. Public Health 2017, 14, 1458. [CrossRef] [PubMed]

4. Zhu, X.; Qiu, H.; Wang, L.; Duan, Z.; Yu, H.; Deng, R.; Zhang, Y.; Zhou, L. Risks of hospital admissions from a spectrum of causes associated with particulate matter pollution. Sci. Total Environ. 2019, 656, 90-100. [CrossRef] [PubMed]

5. Lademann, J.; Schaefer, H.; Otberg, N.; Teichmann, A.; Blume-Peytavi, U.; Sterry, W. Penetration von Mikropartikeln in die menschliche Haut. Der Hautarzt 2004, 55, 1117-1119. [CrossRef] [PubMed]

6. Song, S.; Lee, K.; Lee, Y.-M.; Lee, J.-H.; Lee, S.I.; Yu, S.-D.; Paek, D. Acute health effects of urban fine and ultrafine particles on children with atopic dermatitis. Environ. Res. 2011, 111, 394-399. [CrossRef] [PubMed]

7. Ahn, K. The role of air pollutants in atopic dermatitis. J. Allergy Clin. Immunol. 2014, 134, 993-999. [CrossRef]

8. Jin, S.-P.; Li, Z.; Choi, E.K.; Lee, S.; Kim, Y.K.; Seo, E.Y.; Chung, J.H.; Cho, S. Urban particulate matter in air pollution penetrates into the barrier-disrupted skin and produces ROS-dependent cutaneous inflammatory response in vivo. J. Dermatol. Sci. 2018, 91, 175-183. [CrossRef] [PubMed]

9. Kim, K.E.; Cho, D.; Park, H.J. Air pollution and skin diseases: Adverse effects of airborne particulate matter on various skin diseases. Life Sci. 2016, 152, 126-134. [CrossRef] [PubMed]

10. Lee, D.U.; Ji, M.J.; Kang, J.Y.; Kyung, S.Y.; Hong, J.H. Dust particles-induced intracellular Ca2+ signaling and reactive oxygen species in lung fibroblast cell line MRC5. Korean J. Physiol. Pharmacol. 2017, 21, 327-334. [CrossRef] [PubMed]

11. Tsuji, G.; Takahara, M.; Uchi, H.; Takeuchi, S.; Mitoma, C.; Moroi, Y.; Furue, M. An environmental contaminant, benzo(a)pyrene, induces oxidative stress-mediated interleukin-8 production in human keratinocytes via the aryl hydrocarbon receptor signaling pathway. J. Dermatol. Sci. 2011, 62, 42-49. [CrossRef] [PubMed]

12. Verma, V.; Shafer, M.M.; Schauer, J.J.; Sioutas, C. Contribution of transition metals in the reactive oxygen species activity of PM emissions from retrofitted heavy-duty vehicles. Atmos. Environ. 2010, 44, 5165-5173. [CrossRef]

13. Ryu, Y.S.; Kang, K.A.; Piao, M.J.; Ahn, M.J.; Yi, J.M.; Hyun, Y.-M.; Kim, S.H.; Ko, M.K.; Park, C.O.; Hyun, J.W. Particulate matter induces inflammatory cytokine production via activation of NFKB by TLR5-NOX4-ROS signaling in human skin keratinocyte and mouse skin. Redox Biol. 2019, 21, 101080. [CrossRef] [PubMed]

14. Seok, J.K.; Cho, M.A.; Ha, J.W.; Boo, Y.C. Role of Dual Oxidase 2 in Reactive Oxygen Species Production Induced by Airborne Particulate Matter PM10 in Human Epidermal Keratinocytes. J. Soc. Cosmet. Sci. Korea 2018, 45, 57-67. [CrossRef]

15. Ko, E.; Choi, H.; Park, K.-N.; Park, J.-Y.; Lee, T.R.; Shin, N.W.; Bae, Y.S. Dual oxidase 2 is essential for house dust mite-induced pro-inflammatory cytokine production in human keratinocytes. Exp. Dermatol. 2015, 24, 936-941. [CrossRef] [PubMed]

16. Lee, C.-W.; Lin, Z.-C.; Hsu, L.-F.; Fang, J.-Y.; Chiang, Y.-C.; Tsai, M.-H.; Lee, M.-H.; Li, S.-Y.; Hu, S.C.-S.; Lee, I.-T.; et al. Eupafolin ameliorates COX-2 expression and PGE2 production in particulate pollutants-exposed human keratinocytes through ROS/MAPKs pathways. J. Ethnopharmacol. 2016, 189, 300-309. [CrossRef]

17. Ha, J.W.; Song, H.; Hong, S.S.; Boo, Y.C. Marine Alga Ecklonia cava Extract and Dieckol Attenuate Prostaglandin E2 Production in HaCaT Keratinocytes Exposed to Airborne Particulate Matter. Antioxidants 2019, 8, 190. [CrossRef] [PubMed]

18. Seok, J.K.; Lee, J.-W.; Kim, Y.M.; Boo, Y.C. Punicalagin and (-)-Epigallocatechin-3-Gallate Rescue Cell Viability and Attenuate Inflammatory Responses of Human Epidermal Keratinocytes Exposed to Airborne Particulate Matter PM10. Ski. Pharmacol. Physiol. 2018, 31, 134-143. [CrossRef] [PubMed]

19. Kim, M.; Kim, J.H.; Jeong, G.J.; Park, K.Y.; Lee, M.; Seo, S.J. Particulate matter induces pro-inflammatory cytokines via phosphorylation of p38 MAPK possibly leading to dermal inflammaging. Exp. Dermatol. 2019, 28, 809-815. [CrossRef] [PubMed]

20. Boo, Y.C. p-Coumaric Acid as An Active Ingredient in Cosmetics: A Review Focusing on its Antimelanogenic Effects. Antioxidants 2019, 8, 275. [CrossRef] 
21. Boo, Y.C. Human Skin Lightening Efficacy of Resveratrol and Its Analogs: From In Vitro Studies to Cosmetic Applications. Antioxidants 2019, 8, 332. [CrossRef] [PubMed]

22. Boo, Y.C. Emerging Strategies to Protect the Skin from Ultraviolet Rays Using Plant-Derived Materials. Antioxidants 2020, 9, 637. [CrossRef] [PubMed]

23. Boo, Y. Arbutin as a Skin Depigmenting Agent with Antimelanogenic and Antioxidant Properties. Antioxidants 2021, 10, 1129. [CrossRef] [PubMed]

24. Pasciu, V.; Posadino, A.M.; Cossu, A.; Sanna, B.; Tadolini, B.; Gaspa, L.; Marchisio, A.; Dessole, S.; Capobianco, G.; Pintus, G. Akt Downregulation by Flavin Oxidase-Induced ROS Generation Mediates Dose-Dependent Endothelial Cell Damage Elicited by Natural Antioxidants. Toxicol. Sci. 2010, 114, 101-112. [CrossRef]

25. Posadino, A.M.; Cossu, A.; Giordo, R.; Zinellu, A.; Sotgia, S.; Vardeu, A.; Hoa, P.T.; Deiana, L.; Carru, C.; Pintus, G. Coumaric Acid Induces Mitochondrial Damage and Oxidative-Mediated Cell Death of Human Endothelial Cells. Cardiovasc. Toxicol. 2013, 13, 301-306. [CrossRef]

26. Giordo, R.; Cossu, A.; Pasciu, V.; Hoa, P.T.; Posadino, A.M.; Pintus, G. Different Redox Response Elicited by Naturally Occurring Antioxidants in Human Endothelial Cells. Open Biochem. J. 2013, 7, 44-53. [CrossRef] [PubMed]

27. Bouayed, J.; Bohn, T. Exogenous Antioxidants-Double-Edged Swords in Cellular Redox State: Health Beneficial Effects at Physiologic Doses versus Deleterious Effects at High Doses. Oxidative Med. Cell. Longev. 2010, 3, 228-237. [CrossRef] [PubMed]

28. Boo, Y.C. Can Plant Phenolic Compounds Protect the Skin from Airborne Particulate Matter? Antioxidants 2019, 8, 379. [CrossRef] [PubMed]

29. Boo, Y.C. Natural Nrf2 Modulators for Skin Protection. Antioxidants 2020, 9, 812. [CrossRef]

30. Wang, Q.; Liang, Y.-Y.; Li, K.-W.; Li, Y.; Niu, F.-J.; Zhou, S.-J.; Wei, H.-C.; Zhou, C.-Z. Herba Siegesbeckiae: A review on its traditional uses, chemical constituents, pharmacological activities and clinical studies. J. Ethnopharmacol. 2021, $275,114117$. [CrossRef] [PubMed]

31. Tao, H.-X.; Xiong, W.; Zhao, G.-D.; Peng, Y.; Zhong, Z.-F.; Xu, L.; Duan, R.; Tsim, K.W.; Yu, H.; Wang, Y.-T. Discrimination of three Siegesbeckiae Herba species using UPLC-QTOF/MS-based metabolomics approach. Food Chem. Toxicol. 2018, 119, 400-406. [CrossRef]

32. Guo, H.; Zhang, Y.; Cheng, B.C.-Y.; Lau, M.-Y.; Fu, X.-Q.; Li, T.; Su, T.; Zhu, P.-L.; Chan, Y.-C.; Tse, A.K.-W.; et al. Comparison of the chemical profiles and inflammatory mediator-inhibitory effects of three Siegesbeckia herbs used as Herba Siegesbeckiae (Xixiancao). BMC Complement. Altern. Med. 2018, 18, 141. [CrossRef]

33. Boukamp, P.; Petrussevska, R.T.; Breitkreutz, D.; Hornung, J.; Markham, A.; Fusenig, N.E. Normal keratinization in a spontaneously immortalized aneuploid human keratinocyte cell line. J. Cell Biol. 1988, 106, 761-771. [CrossRef]

34. Denizot, F.; Lang, R. Rapid colorimetric assay for cell growth and survival. Modifications to the tetrazolium dye procedure giving improved sensitivity and reliability. J. Immunol. Methods 1986, 89, 271-277. [CrossRef]

35. Lee, J.-W.; Seok, J.K.; Boo, Y.C. Ecklonia cava Extract and Dieckol Attenuate Cellular Lipid Peroxidation in Keratinocytes Exposed to PM10. Evid.-Based Complement. Altern. Med. 2018, 2018, 8248323. [CrossRef]

36. Eruslanov, E.; Kusmartsev, S. Identification of ROS Using Oxidized DCFDA and Flow-Cytometry. Methods Mol. Biol. 2010, 594, 57-72. [CrossRef] [PubMed]

37. Tietze, F. Enzymic method for quantitative determination of nanogram amounts of total and oxidized glutathione: Applications to mammalian blood and other tissues. Anal. Biochem. 1969, 27, 502-522. [CrossRef]

38. Sun, X.; Li, B.; Li, X.; Wang, Y.; Xu, Y.; Jin, Y.; Piao, F.; Sun, G. Effects of sodium arsenite on catalase activity, gene and protein expression in HaCaT cells. Toxicol. Vitr. 2006, 20, 1139-1144. [CrossRef] [PubMed]

39. Rolfs, F.; Huber, M.; Kuehne, A.; Kramer, S.; Haertel, E.; Muzumdar, S.; Wagner, J.; Tanner, Y.; Böhm, F.; Smola, S.; et al. Nrf2 Activation Promotes Keratinocyte Survival during Early Skin Carcinogenesis via Metabolic Alterations. Cancer Res. 2015, 75, 4817-4829. [CrossRef]

40. Kanno, T.; Tanaka, K.; Yanagisawa, Y.; Yasutake, K.; Hadano, S.; Yoshii, F.; Hirayama, N.; Ikeda, J.-E. A novel small molecule, N-(4-(2-pyridyl)(1,3-thiazol-2-yl))-2-(2,4,6-trimethylphenoxy) acetamide, selectively protects against oxidative stress-induced cell death by activating the Nrf2-ARE pathway: Therapeutic implications for ALS. Free. Radic. Biol. Med. 2012, 53, $2028-2042$. [CrossRef]

41. Priftis, A.; Angeli-Terzidou, A.; Veskoukis, A.S.; Spandidos, D.; Kouretas, D. Cell-specific and roasting-dependent regulation of the Keap1/Nrf2 pathway by coffee extracts. Mol. Med. Rep. 2018, 17, 8325-8331. [CrossRef] [PubMed]

42. Lim, K.H.; Ku, J.-E.; Rhie, S.-J.; Ryu, J.Y.; Bae, S.; Kim, Y.-S. Anti-oxidant and Anti-inflammatory Effects of Sinapic Acid in UVB Irradiation-Damaged HaCaT Keratinocytes. Asian J. Beauty Cosmetol. 2017, 15, 513-522. [CrossRef]

43. Lou, D.; Wei, X.; Xiao, P.; Huo, Q.; Hong, X.; Sun, J.; Shuai, Y.; Tao, G. Demethylation of the NRF2 Promoter Protects against Carcinogenesis Induced by Nano-SiO2. Front. Genet. 2020, 11, 818. [CrossRef]

44. Warabi, E.; Wada, Y.; Kajiwara, H.; Kobayashi, M.; Koshiba, N.; Hisada, T.; Shibata, M.; Ando, J.; Tsuchiya, M.; Kodama, T.; et al. Effect on Endothelial Cell Gene Expression of Shear Stress, Oxygen Concentration, and Low-Density Lipoprotein as Studied by a Novel Flow Cell Culture System. Free. Radic. Biol. Med. 2004, 37, 682-694. [CrossRef] [PubMed]

45. Zhao, R.; Hou, Y.; Zhang, Q.; Woods, C.G.; Xue, P.; Fu, J.; Yarborough, K.; Guan, D.; Andersen, M.; Pi, J. Cross-Regulations among NRFs and KEAP1 and Effects of their Silencing on Arsenic-Induced Antioxidant Response and Cytotoxicity in Human Keratinocytes. Environ. Health Perspect. 2012, 120, 583-589. [CrossRef] [PubMed] 
46. Jeong, S.-H. Anti-oxidant Activities of Phytol on Keratinocytes. Asian J. Beauty Cosmetol. 2017, 15, 457-465. [CrossRef]

47. An, S.-M.; Koh, J.-S.; Boo, Y.-C. Inhibition of melanogenesis by tyrosinase siRNA in human melanocytes. BMB Rep. 2009, 42, 178-183. [CrossRef]

48. Limón-Pacheco, J.; Gonsebatt, M.E. The role of antioxidants and antioxidant-related enzymes in protective responses to environmentally induced oxidative stress. Mutat. Res. Toxicol. Environ. Mutagen. 2009, 674, 137-147. [CrossRef]

49. Kalinina, E.V.; Chernov, N.N.; Novichkova, M.D. Role of glutathione, glutathione transferase, and glutaredoxin in regulation of redox-dependent processes. Biochemistry 2014, 79, 1562-1583. [CrossRef]

50. Gong, Z.-H.; Tian, G.-L.; Huang, Q.-W.; Wang, Y.-M.; Xu, H.-P. Reduced glutathione and glutathione disulfide in the blood of glucose-6-phosphate dehydrogenase-deficient newborns. BMC Pediatr. 2017, 17, 172. [CrossRef]

51. Hoffmann, C.; Dietrich, M.; Herrmann, A.-K.; Schacht, T.; Albrecht, P.; Methner, A. Dimethyl Fumarate Induces Glutathione Recycling by Upregulation of Glutathione Reductase. Oxidative Med. Cell. Longev. 2017, 2017, 6093903. [CrossRef]

52. Föller, M.; Harris, I.S.; Elia, A.; John, R.; Lang, F.; Kavanagh, T.J.; Mak, T.W. Functional significance of glutamate-cysteine ligase modifier for erythrocyte survival in vitro and in vivo. Cell Death Differ. 2013, 20, 1350-1358. [CrossRef]

53. Beyer, T.A.; Keller, U.A.D.; Braun, S.; Schäfer, M.; Werner, S. Roles and mechanisms of action of the Nrf2 transcription factor in skin morphogenesis, wound repair and skin cancer. Cell Death Differ. 2007, 14, 1250-1254. [CrossRef] [PubMed]

54. He, F.; Ru, X.; Wen, T. NRF2, a Transcription Factor for Stress Response and Beyond. Int. J. Mol. Sci. 2020, 21, 4777. [CrossRef]

55. Yamamoto, M.; Kensler, T.W.; Motohashi, H. The KEAP1-NRF2 System: A Thiol-Based Sensor-Effector Apparatus for Maintaining Redox Homeostasis. Physiol. Rev. 2018, 98, 1169-1203. [CrossRef]

56. Wang, D.; Hou, J.; Wan, J.; Yang, Y.; Liu, S.; Li, X.; Li, W.; Dai, X.; Zhou, P.; Liu, W.; et al. Dietary chlorogenic acid ameliorates oxidative stress and improves endothelial function in diabetic mice via Nrf2 activation. J. Int. Med. Res. 2021, 49, 300060520985363. [CrossRef]

57. Han, D.; Chen, W.; Gu, X.; Shan, R.; Zou, J.; Liu, G.; Shahid, M.; Gao, J.; Han, B. Cytoprotective effect of chlorogenic acid against hydrogen peroxide-induced oxidative stress in MC3T3-E1 cells through PI3K/Akt-mediated Nrf2/HO-1 signaling pathway. Oncotarget 2017, 8, 14680-14692. [CrossRef] [PubMed]

58. Bao, L.; Li, J.; Zha, D.; Zhang, L.; Gao, P.; Yao, T.; Wu, X. Chlorogenic acid prevents diabetic nephropathy by inhibiting oxidative stress and inflammation through modulation of the Nrf2/HO-1 and NF-kB pathways. Int. Immunopharmacol. 2018, 54, 245-253. [CrossRef]

59. Wang, J.-P.; Ruan, J.-L.; Cai, Y.-L.; Luo, Q.; Xu, H.-X.; Wu, Y.-X. In vitro and in vivo evaluation of the wound healing properties of Siegesbeckia pubescens. J. Ethnopharmacol. 2011, 134, 1033-1038. [CrossRef] [PubMed]

60. Wang, J.; Cai, Y.; Wu, Y. Antiinflammatory and analgesic activity of topical administration of Siegesbeckia pubescens. Pak. J. Pharm. Sci. 2008, 21, 89-91. [PubMed]

61. Sang, W.; Zhong, Z.; Linghu, K.; Xiong, W.; Tse, A.K.W.; Cheang, W.S.; Yu, H.; Wang, Y. Siegesbeckia pubescens Makino inhibits Pam3CSK4-induced inflammation in RAW 264.7 macrophages through suppressing TLR1/TLR2-mediated NF- $\mathrm{kB}$ activation. Chin. Med. 2018, 13, 37. [CrossRef] [PubMed]

62. Li, Y.-S.; Zhang, J.; Tian, G.-H.; Shang, H.-C.; Tang, H.-B. Kirenol, darutoside and hesperidin contribute to the anti-inflammatory and analgesic activities of Siegesbeckia pubescens makino by inhibiting COX-2 expression and inflammatory cell infiltration. J. Ethnopharmacol. 2021, 268, 113547. [CrossRef] [PubMed]

63. Lee, S.-G.; Kim, M.; Kim, C.E.; Kang, J.; Yoo, H.; Sung, S.H.; Lee, M. Quercetin 3,7-O-dimethyl ether from Siegesbeckia pubescens suppress the production of inflammatory mediators in lipopolysaccharide-induced macrophages and colon epithelial cells. Biosci. Biotechnol. Biochem. 2016, 80, 2080-2086. [CrossRef] [PubMed]

64. Lee, M.; Kim, S.H.; Lee, H.K.; Cho, Y.; Kang, J.; Sung, S.H. ent-Kaurane and ent-Pimarane Diterpenes from Siegesbeckia pubescens Inhibit Lipopolysaccharide-Induced Nitric Oxide Production in BV2 Microglia. Biol. Pharm. Bull. 2014, 37, 152-157. [CrossRef] [PubMed]

65. Lee, D.-S.; Lee, M.; Sung, S.H.; Jeong, G.S. Involvement of heme oxygenase-1 induction in the cytoprotective and neuroinflammatory activities of Siegesbeckia pubescens isolated from 5,3'-dihydroxy-3,7,4'-trimethoxyflavone in HT22 cells and BV2 cells. Int. Immunopharmacol. 2016, 40, 65-72. [CrossRef] [PubMed]

66. Kim, D.-W.; Jung, D.-H.; Sung, J.; Min, I.; Lee, S.-J. Tart Cherry Extract Containing Chlorogenic Acid, Quercetin, and Kaempferol Inhibits the Mitochondrial Apoptotic Cell Death Elicited by Airborne PM $_{10}$ in Human Epidermal Keratinocytes. Antioxidants 2021, 10, 443. [CrossRef] [PubMed]

67. Peng, L.; Wang, B.; Ren, P. Reduction of MTT by flavonoids in the absence of cells. Colloids Surf. B Biointerfaces 2005, 45, 108-111. [CrossRef] [PubMed]

68. Holder, A.; Goth-Goldstein, R.; Lucas, D.; Koshland, C.P. Particle-Induced Artifacts in the MTT and LDH Viability Assays. Chem. Res. Toxicol. 2012, 25, 1885-1892. [CrossRef] [PubMed]

69. Habtemariam, S. Catechols and quercetin reduce MTT through iron ions: A possible artefact in cell viability assays. Phytother. Res. 1995, 9, 603-605. [CrossRef] 